\title{
Efficient Lignin Depolymerization with Ru- and W- modified Bi-functional Solid Acid Catalyst
}

\begin{abstract}
Shengxin An, ${ }^{\mathrm{a}}$ Jindong Wang, ${ }^{\mathrm{b}}$ Zean Zhou, ${ }^{\mathrm{b}}$ Baikai Zhang, ${ }^{\mathrm{b}}$ Fengyang Xue, Huizhen Wang, ${ }^{\mathrm{b}}$ and Wenzhi Li ${ }^{\mathrm{b}, *}$

A novel Ru-modified composite catalyst, Ru-W/Sn-AlOx, was prepared, and the effects of the catalyst on lignin depolymerization were investigated in this study. The catalyst converted approximately $95 \%$ lignin into liquid product at $300^{\circ} \mathrm{C}$ in $12 \mathrm{~h}$ and $2 / 3$ of the liquid product could be soluble in petroleum ether. The petroleum ether (PE) soluble product was mainly composed of monomers, dimers and some trimmers. This indeed indicated that the catalyst could effectively depolymerize lignin into smallmolecule products. $7.22 \%$ of monomers was obtained at $310{ }^{\circ} \mathrm{C}$ for $12 \mathrm{~h}$. Meanwhile, the catalyst effectively reduced the char formation to $2 \%$. After the catalytic depolymerization, the higher heating value (HHV) of the liquid product increased from 25.7 to $32.4 \mathrm{MJ} / \mathrm{kg}$. The product could be utilized as fuel additive or converted to biofuels. This catalysis system showed great potential in the conversion of lignin into biofuels.
\end{abstract}

DOI: 10.15376/biores.17.1.1062-1089

Keywords: Lignin; Depolymerization; Solid catalyst; Ru-W/Sn-AlOx

Contact information: a: Institute of Chemical Engineering, Anhui University of Science and Technology, Huainan 232001, PR China; b: Laboratory of Basic Research in Biomass Conversion and Utilization, Department of Thermal Science and Energy Engineering, University of Science and Technology of China, Hefei 230026, PR China; *Corresponding author: liwenzhi@ustc.edu.cn

\section{INTRODUCTION}

Along with the development of economy, the increasing consumption of fossil feedstock (i.e., crude oil and natural gas) has caused many environmental problems. Among the problems, increasing anthropogenic carbon emissions is one of the most serious challenges facing human development. Many countries have developed policy approaches to reduce global carbon (mainly $\mathrm{CO}_{2}$ ) emissions. Biomass is regarded as the only renewable carbon-neutral energy source (Shi et al. 2013; Jiang et al. 2018; Hu et al. 2019). Replacing the fossil feedstock with biomass has been increasingly researched (Lin et al. 2017a,b; Wang et al. 2017; Wu et al. 2018, 2020) and continues to receive increased attention. Many companies employ biomass as fuel to reach the goal of zero carbon emissions. However, compared with coal or other fuels, the oxygen content of biomass is relatively higher and the heat efficiency is lower. Therefore, finding methods to utilize biomass effectively is meaningful.

Lignocellulosic biomass contains cellulose, hemicellulose, and lignin. As an important component of biomass, lignin is the richest and most renewable source containing plentiful aromatic polymers (Wang et al. 2020; Wu et al. 2020). Lignin has high potential value to be converted to liquid fuel and fine chemicals. On the other hand, lignin is not as well effectively utilized as the other components of biomass (Shi et al. 2018). The reason is that lignin has a complex three-dimensional, amorphous polymeric structure, 
which makes it difficult to depolymerize. Thus, exploiting an efficient method to depolymerize lignin is necessary.

To this day, many efforts have been devoted to develop efficient methods to utilize lignin. In previous work, lignin has been depolymerized by some simple converted processes, such as oxidation, hydrogenation, acid-catalysis, base-catalysis, and so on (Ma et al. 2019a; Cai et al. 2020; Zhang et al. 2020). For the oxidation process, Das et al. (2018) converted lignin to low-molecular-weight aromatics via an aerobic oxidation hydrolysis. For hydrogenation, Zhang et al. (2018) used $\mathrm{Ni} / \mathrm{SiO}_{2}$ to convert lignin-derived phenolics to hydrocarbon fuel. For acid and base methods, Dabral et al. (2018) studied the mechanism of base-catalysed lignin depolymerization and Zhou et al. (2019) employed the lignin depolymerization process by solid acid catalyst. Some researchers investigated solvolytic and thermal depolymerization (Jiang et al. 2014; Zhou et al. 2016). Although these methods can efficiently depolymerize lignin, they have some drawbacks. The oxidative methods can give rise to complex products, and the reaction conditions are hard to control (Liu et al. 2019; Thijs et al. 2018; Yao et al. 2018). The hydrogenation methods need relatively harsh conditions such as high temperature, long reaction time, and so on. Additionally, these methods usually have employed noble metals such as $\mathrm{Ru}, \mathrm{Pt}$, and $\mathrm{Pd}$. The acid or base catalytic methods suffer from serious char formation (Zakzeski et al. 2010). As for solvolytic and thermal methods for the lignin depolymerization, the monomer yield is relatively low (Zhang et al. 2020).

In order to solve the problems in the depolymerization of lignin, such as low yield of low molecular weight of the product, high char formation, and poor product selectivity (Rinaldi et al. 2016), researchers have made many efforts and employed some new methods, such as combining two or more methods together for the depolymerization of lignin. Limarta et al. (2018) and Long et al. (2015) used base and hydrogenation catalyst together in lignin degradation. Rahimi et al. (2014) employed formic acid in lignin oxidative depolymerization. In other research, the hydrogenation method and acid catalytic depolymerization method were also used together. Generally speaking, reductive depolymerization is a hydrogenation process with a catalyst $(\mathrm{Ru}$ or $\mathrm{Pt})$ and a hydrogen donating species (hydrogen gas or methanol). It can effectively convert lignin to liquid product and reduce the char formation, but its drawback is low yield of low molecular weight product (Van den Bosch et al. 2015). Harsh hydroprocessing at high temperature $\left(>320{ }^{\circ} \mathrm{C}\right.$ ) and hydrogen pressure (> 35 bar) could solve the problem mentioned above but it has been shown to require high energy consumption (Kloekhorst and Heeres 2016). Acidcatalyzed depolymerization can provide a relatively high yield of small molecular product (Zhang et al. 2014). However, it suffers from high char formation. When both hydroprocessing and acid-catalyzed depolymerization were used together, the hydroprocessing could stabilize the intermediates to reduce the char formation and acidcatalyzed depolymerization could maintain the high yield of small molecular product (Bjelic et al. 2019). Moreover, the acid (especially Lewis acid) could weaken the C-O bond and facilitate hydrodeoxygenation in the presence of hydrogenation catalyst (Liao et al. 2014; Liu et al. 2015; Shao et al. 2017). Since the two methods are complementary, the combined acid-hydrogenation method has become increasingly popular over the years. Many researchers physically mixed acid and hydrogenation catalyst or prepared a bifunctional catalyst to depolymerize lignin (Shu et al. 2016; Yan et al. 2017; Ma et al. 2019b, 2019c).

According to the above information, a Ru-modified acid catalyst was explored in this research. Since the acidity had great impact on lignin depolymerization, the acid part 
of the catalyst was also carefully chosen and well researched. The stannic and aluminium oxide are strong Lewis acids. $\mathrm{SnO}_{2}$ can be used as a strong Lewis acid carrier (Heda et al. 2019). The $\mathrm{Al}_{2} \mathrm{O}_{3}$ could also play a similar role ( $\mathrm{Zhu}$ et al. 2019). In addition, because the valences of $\mathrm{Sn}$ and $\mathrm{Al}$ are different, their combination could also generate many active sites and improve the property (Li et al. 1994; Kurmach et al. 2019). The $\mathrm{WO}_{3}$ has always been employed as a Lewis acid (Wang et al. 2016). Studies had shown that the combination of an appropriate amount of metal $\mathrm{W}$ and $\mathrm{WO}_{3}$ was favorable for breaking the $\beta-\mathrm{O}-4$ bonds in lignin (Guo et al. 2019). In addition, $\mathrm{WO}_{3}$ could also accelerate the hydrodeoxygenation reaction of lignin derivatives (Rasmussen and Medlin 2020; Wang, et al. 2014). Hence, the $\mathrm{W}$-modified method was supposed to enhance the acidity of the catalyst. The effect of this modified method was researched in the present work and the details were studied. Meanwhile, an acid-hydrogenation bifunctional catalyst, Ru-W/Sn-AlOx, was synthesized and used into a one-pot lignin conversion reaction at 1,4-dioxane and methanol system. A gas chromatograph-mass spectrometer (GC-MS), gas chromatograph (GC), and elemental analysis were employed in the product analysis. The catalyst was analyzed by scanning electron microscopy (SEM), Brunner-Emmet-Teller (BET) measurements, temperature programmed desorption (TPD), and X-ray diffraction (XRD) analyses. The effects of reaction conditions were considered, and the effects of the acid and hydrogenation components of the catalyst were also investigated.

\section{EXPERIMENTAL}

\section{Materials}

The lignin, Indulin $\mathrm{AT}^{\mathrm{TM}}$, was bought from MeadWestvaco (Shanghai, China). The basic chemical characteristics of Indulin $\mathrm{AT}^{\mathrm{TM}}$ are shown in Table $\mathrm{S} 1 . \mathrm{RuCl}_{3}$, acetophenone, phenol, guaiacol, veratrole, 4-ethylphenol, 2-methoxy-4-methyl-phenol, 3,4-dimethoxytoluene, 2-methoxy-4-ethyl-phenol, syringol, 2-methoxy-4-propyl-phenol, vanilline, isoeugenol, acetovanillone, 2,6-ditert-butyl-4-methyl phenol, 3,4-dimethoxyacetophenone, and homovanillic acid were purchased from Aladdin (Shanghai, China). $\mathrm{SnCl}_{4} \cdot 5 \mathrm{H}_{2} \mathrm{O}, \mathrm{Al}\left(\mathrm{NO}_{3}\right)_{3} \cdot 9 \mathrm{H}_{2} \mathrm{O}, \mathrm{NH}_{3} \cdot \mathrm{H}_{2} \mathrm{O}, \mathrm{H}_{3} \mathrm{O}_{40} \mathrm{PW}_{12} \cdot \mathrm{xH}_{2} \mathrm{O}$, ethanol, $\mathrm{NaBH}_{4}$, methanol, acetone, 1,4-dioxane, and petroleum ether were analytical reagents and produced by Sinopharm Chemical Reagent Co., Ltd. (Shanghai, China). All chemicals were used without further purification.

\section{Methods}

\section{Preparation of catalyst}

The support, $\mathrm{Sn}-\mathrm{AlO}_{\mathrm{x}}$, was prepared by the coprecipitation method. First, $15.381 \mathrm{~g}$ $\mathrm{SnCl}_{4} \cdot 5 \mathrm{H}_{2} \mathrm{O}$ and $19.732 \mathrm{Al}\left(\mathrm{NO}_{3}\right)_{3} \cdot 9 \mathrm{H}_{2} 0$ were dissolved in $200 \mathrm{~mL}$ ultrapure water. After adjustment $\mathrm{pH}$ to 10 using $\mathrm{NH}_{3} \cdot \mathrm{H}_{2} \mathrm{O}$, the mixture was stirred for $30 \mathrm{~min}$. After $2 \mathrm{~h}$ of precipitation, the solution was stirred in a water bath at $80{ }^{\circ} \mathrm{C}$ for $6 \mathrm{~h}$ and then dried at 105 ${ }^{\circ} \mathrm{C}$ for $12 \mathrm{~h}$. After being ground, the following step was calcination at $300{ }^{\circ} \mathrm{C}$ for $2 \mathrm{~h}$ and then $500{ }^{\circ} \mathrm{C}$ for $3 \mathrm{~h}$ with a heating rate of $3{ }^{\circ} \mathrm{C} / \mathrm{min}$.

Next, the preparation of $\mathrm{W} / \mathrm{Sn}$ - $\mathrm{AlO}_{\mathrm{x}}$ was carried out: $1.126 \mathrm{~g}$ phosphotungstic acid, $8.0 \mathrm{~g} \mathrm{Sn}-\mathrm{AlO}_{\mathrm{x}}$ powder, and $80 \mathrm{~mL}$ distilled water were added in a $100-\mathrm{mL}$ beaker. After 2 $\mathrm{h}$ of stirring, the sample was heated in $60{ }^{\circ} \mathrm{C}$ water baths for $2 \mathrm{~h}$. Then the mixture was dried in an oven at $105{ }^{\circ} \mathrm{C}$ for $12 \mathrm{~h}$. After grinding into powder, the sample was calcined at $300{ }^{\circ} \mathrm{C}$ for $2 \mathrm{~h}$ and $550{ }^{\circ} \mathrm{C}$ for $3 \mathrm{~h}$ with a heating rate of $3{ }^{\circ} \mathrm{C} / \mathrm{min}$ and then grinded. 
Next, the preparation of $\mathrm{Ru}-\mathrm{W} / \mathrm{Sn}-\mathrm{AlO}_{\mathrm{x}}$ was as follows: $10 \mathrm{~mL}$ of $\mathrm{RuCl}_{3}$ solution $\left(0.1026 \mathrm{~g} \mathrm{RuCl}_{3}\right)$ and $1 \mathrm{~g}$ of $\mathrm{W} / \mathrm{Sn}-\mathrm{AlO}_{\mathrm{x}}$ powder were added to the mixed solution of 40 $\mathrm{mL}$ ethanol and $60 \mathrm{~mL}$ distilled water. After $6 \mathrm{~h}$ stirring, $100 \mathrm{~mL}$ of $\mathrm{NaBH}_{4}$ solution $(2 \mathrm{~g}$ $\mathrm{NaBH}_{4}$ ) was added dropwise into the above mixture. After $12 \mathrm{~h}$ stirring, the $\mathrm{Ru}-\mathrm{W} / \mathrm{Sn}-$ $\mathrm{AlO}_{\mathrm{x}}$ was first filtered, then washed by ethanol and distilled water, and finally dried in a vacuum at $70{ }^{\circ} \mathrm{C}$ for $12 \mathrm{~h}$. After being ground, $\mathrm{Ru}-\mathrm{W} / \mathrm{Sn}-\mathrm{AlO}_{\mathrm{x}}(\mathrm{Ru}: 5 \mathrm{wt} \%)$ was achieved. The $5 \mathrm{wt} \% \mathrm{Ni}(\mathrm{Pt}, \mathrm{Pd}$, or $\mathrm{Rh})-\mathrm{W} / \mathrm{Sn}-\mathrm{AlO}_{\mathrm{x}}$ was prepared using a similar method.

\section{Depolymerization of lignin}

Before the reaction, $30 \mathrm{~mL}$ 1,4-dioxane and $6 \mathrm{~mL}$ methanol were mixed. The volume ratio of the two solvents was calculated by solubility parameter computations from Howell et al. (2017). Lignin could be completely dissolved in the described solvent mixture. The depolymerization reaction was conducted in a stainless steel autoclave reactor. First, $0.5 \mathrm{~g}$ of lignin was dissolved in the solvent mixture solvent ultrasonic conditions, and then $0.1 \mathrm{~g}$ of the catalyst was added. The resulting mixture was transferred into the reactor. After passing a leak test and completely purging out the air from the reactor, the reactor was pressurized to $2.0 \mathrm{MPa}$ with $\mathrm{H}_{2}$. The reactor was then heated to a specified reaction temperature $\left(270,290,300\right.$, and $\left.310^{\circ} \mathrm{C}\right)$ for a specified time period $(1$ $\mathrm{h}, 3 \mathrm{~h}, 6 \mathrm{~h}$, and $12 \mathrm{~h}$ ) under stirring at $900 \mathrm{rpm}$. The effects of different reaction times, reaction temperatures, and catalysts on lignin depolymerization were investigated. At the end of reaction time, the reactor was cooled down in air and the residual solid was separated from the liquid product by filtration. For the liquid product, a tiny aliquot was set aside for GC and GC/MS analysis.

The monomers in the liquid product were identified by a gas chromatography/mass spectrometry (GC/MS, QP2010S, Shimadzu, Kyoto, Japan) equipped with an Rtx-5MS column $(30 \mathrm{~m} \times 25 \mathrm{~mm} \times 0.25 \mu \mathrm{m})$. The oven temperature was programmed as $40{ }^{\circ} \mathrm{C}$ held for $3 \mathrm{~min}$, ramped up to $180^{\circ} \mathrm{C}$ with $4{ }^{\circ} \mathrm{C} / \mathrm{min}$, and then to $260{ }^{\circ} \mathrm{C}$ with $10^{\circ} \mathrm{C} / \mathrm{min}$. At last, it was maintained for another $10 \mathrm{~min}$ at $260{ }^{\circ} \mathrm{C}$. Helium was the carrier gas. Quantitative analysis of the monomer products was determined by GC-2010 gas chromatograph (Shimadzu, Kyoto, Japan) with a flame ionization detector (FID) and a WondaCAP5 column (Kyoto, Japan). The oven temperature was held at $50{ }^{\circ} \mathrm{C}$ for $3 \mathrm{~min}$, ramped up to $250{ }^{\circ} \mathrm{C}$ at $10^{\circ} \mathrm{C} / \mathrm{min}$, and then held for another $10 \mathrm{~min}$. The yield was calculated by using acetophenone as an internal standard. The details of the internal standard method are shown in the Supporting Information.

The $\mathrm{C}, \mathrm{H}, \mathrm{O}, \mathrm{N}$, and $\mathrm{S}$ contents (wt $\%$ ) in the liquid product were measured by an elemental analyzer VarioELIII (Elementar, Frankfurt, Germany). The higher heating value (HHV) of the samples was calculated by Dulong's formula (Jindal and Jha 2016; Yang et al. 2016),

$$
H H V(\mathrm{MJ} / \mathrm{kg})=0.335 \times C+1.428 \times(H-O / 8)-0.145 \times N+0.095 \times S
$$

where $C, H, O, N$, and $S$ represent the weight percentages of carbon, hydrogen, oxygen, nitrogen, and sulfur, respectively.

The liquid product was evaporated using a rotary evaporator (Jinghua Instrument Co., Ltd., Zhengzhou, Henan) at $40{ }^{\circ} \mathrm{C}$. The solid product was weighed and dissolved in 1 $\mathrm{mL}$ of acetone. Then, the above acetone solution was added dropwise into $200 \mathrm{~mL}$ petroleum ether with stirring at $400 \mathrm{rpm}$ for $5 \mathrm{~min}$. The sediment formed was separated from the supernatant by centrifugation at $10000 \mathrm{rpm}$ for $5 \mathrm{~min}$. The supernatant was evaporated by rotary evaporator at $40^{\circ} \mathrm{C}$. The remaining part of the solution was weighed. 
According to Jiang et al. (2016), the PE-soluble product consisted of monomers, dimers, trimers, or some slightly bigger multimers for its number-average molecular weight $\left(M_{\mathrm{n}}\right)$, which was about 364 .

The yields of the liquid product, solid product, gas product, and PE-soluble product were calculated as follows,

$$
\begin{aligned}
& \text { Yield of liquid product }(\%)=W_{\mathrm{LP}} / W_{\mathrm{L}} \times 100 \\
& \text { Yield of solid product }(\%)=\left(W_{\mathrm{R}}-W_{\mathrm{C}}\right) / W_{\mathrm{L}} \times 100 \\
& \text { Yield of gas product }(\%)=100-(\text { Yield of liquid product })-(\text { Yield of solid product })
\end{aligned}
$$

Yield of PE-soluble $(\%)=W_{\mathrm{P}} / W_{\mathrm{L}} \times 100$

where $W_{\mathrm{LP}}$ is the weight $(\mathrm{g})$ of the liquid product, $W_{\mathrm{P}}$ is the weight $(\mathrm{g})$ of the PE-soluble product, $W_{\mathrm{R}}$ is the weight $(\mathrm{g})$ of the residual solid, $W_{\mathrm{L}}$ is the weight $(\mathrm{g})$ of the lignin (Indulin $\mathrm{AT})$, and $W_{\mathrm{C}}$ is the weight $(\mathrm{g})$ of the catalyst.

\section{Analysis methods}

The surface morphology of the catalyst was investigated by a scanning electron microscope (SEM) (SIRION 200, FEI Company, Hillsboro, OR, USA), and its textural property was measured by an Autosorbi Q (Quantachrome Instruments, Boynton Beach, FL, USA).

The $\mathrm{NH}_{3}$-temperature programmed desorption ( $\left.\mathrm{NH}_{3}-\mathrm{TPD}\right)$ measurements were performed on an Automatic Chemical Adsorption Instrument (Quantachrome Instruments, Boynton Beach, FL, USA). $100 \mathrm{mg}$ of catalyst sample was pretreated in a flow of helium $\left(30 \mathrm{~mL} / \mathrm{min}\right.$ ) at $300{ }^{\circ} \mathrm{C}$ for $1 \mathrm{~h}$, and after cooling to $100{ }^{\circ} \mathrm{C}$, it was then saturated with $10 \%$ $\mathrm{NH}_{3} / \mathrm{He}$ at $300{ }^{\circ} \mathrm{C}$. Subsequently, the excess, physically adsorbed ammonia was removed by purging with helium at a flow rate of $30 \mathrm{~mL} / \mathrm{min}$ at $100{ }^{\circ} \mathrm{C}$. Finally, the desorption process took place when the temperature rose to $1000^{\circ} \mathrm{C}$ at a rate of $20{ }^{\circ} \mathrm{C} / \mathrm{min}$.

$\mathrm{X}$-ray powder diffraction (XRD) patterns were obtained with a TTR-III (Rigaku Corporation, Tokyo, Japan). All the XRD peaks were assigned according to the Joint Committee on Powder Diffraction Standard Card (JCPDS Card).

X-ray photoelectron spectra (XPS) of the catalysts were obtained using a Thermo ESCALAB 250 (Thermo-VG Scientific, Boston, MA, USA) with a monochromated Al Ka $\mathrm{X}$-ray source $(\mathrm{hv}=1486.6 \mathrm{eV})$, and the binding of energy was calibrated using the $\mathrm{C} 1 \mathrm{~s}$ peak at $284.8 \mathrm{eV}$.

The field-emission transmission electron microscope images of samples were performed on a 200 kV JEOL-JSM-2100F (Japan Electronics Co., Ltd., Tokyo, Japan) instrument with an energy dispersive spectrometer (EDS) detector (Japan Electronics Co., Ltd., Tokyo, Japan).

\section{RESULTS AND DISCUSSION}

\section{Catalyst Characterization}

The SEM images of the catalysts are shown in Fig. S1. It was known that there were three kinds of $\mathrm{Sn}-\mathrm{AlO}_{\mathrm{x}}$ when it was first prepared. They were lamellar, bulk, and rod- 
like $\mathrm{Sn}-\mathrm{AlO}_{\mathrm{x}}$. After modification of $\mathrm{W}$ and $\mathrm{Ru}$, bulk and rodlike $\mathrm{Sn}-\mathrm{AlO}_{\mathrm{x}}$ remained. This indicated that the bulk and rodlike $\mathrm{Sn}-\mathrm{AlO}_{\mathrm{x}}$ were more stable than the lamellar one.

The XRD results are shown in Fig. 1. All the peaks that appeared were typical diffraction peaks of tetragonal $\mathrm{SnO}_{2}$. It can be known that the only crystal structure of $\mathrm{SnAlO}_{x}$ carrier was $\mathrm{SnO}_{2}$. In general, the $\mathrm{Al}(\mathrm{OH})_{3}$ will be converted to alumina crystal through a calcination above $450{ }^{\circ} \mathrm{C}$, while the atom ratio of $\mathrm{Sn}$ and $\mathrm{Al}$ is 1:1 (Levin and Brandon 1998). This might be explained by the fact that the atomic radius of Sn was far bigger than $\mathrm{Al}$ and the $\mathrm{Al}$ atom was dispersed in tetragonal $\mathrm{SnO}_{2}$ crystal lattice. It was as if the $\mathrm{Al}_{2} \mathrm{O}_{3}$ was dissolved in the $\mathrm{SnO}_{2}$ and a solid solution $\mathrm{SnAlOx}$ was formed (Sá et al. 2005). Figure 1 also shows that the modification of $\mathrm{W}$ and $\mathrm{Ru}$ had no obvious effect on the crystal structure of the catalyst and that $\mathrm{W}$ and $\mathrm{Ru}$ were dispersed well on the carrier.

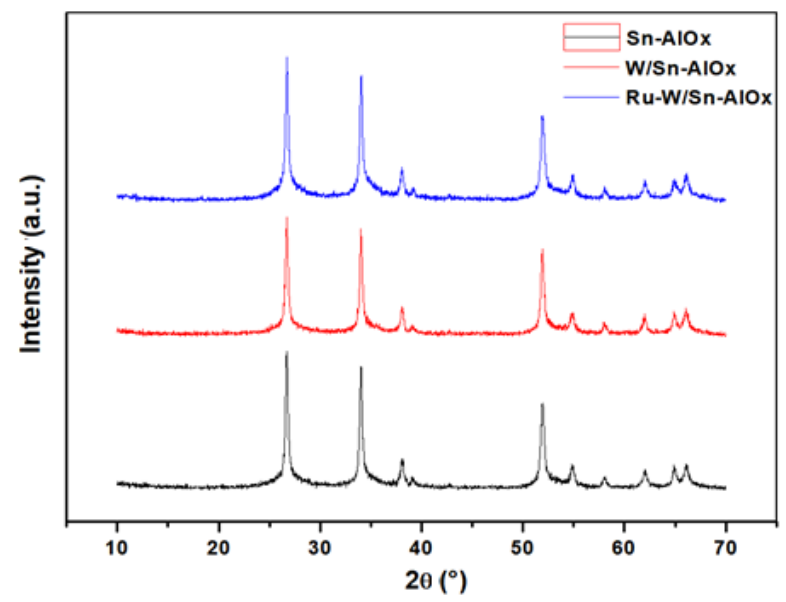

Fig. 1. The XRD pattern of the catalysts

The data of $\mathrm{NH}_{3}-\mathrm{TPD}$ is shown in Table 1. The desorbed temperature represented the strength of the acid sites and the amount of desorbed $\mathrm{NH}_{3}$ represented the amount of acid sites. Entry 1 demonstrated that there were two acid sites in Sn-AlOx, named the weak acid site $\left(205^{\circ} \mathrm{C}, \mathrm{WAS}\right)$ and the strong acid site $\left(550^{\circ} \mathrm{C}, \mathrm{SAS}\right)$. After modification by W (entry 2), the first two acid sites changed a little. The WAS became slightly weaker, and the SAS became slightly stronger. Moreover, a super strong acid site $\left(950{ }^{\circ} \mathrm{C}, \mathrm{SSAS}\right)$ emerged. This indeed showed that the W-modification can enhance the acidity of the catalyst. After being modified by $\mathrm{Ru}$, the SSAS disappeared but the amount of WAS and SAS were obviously increased (entry 3 ). This might be attributed to the reduction process.

The textural properties of the catalysts derived from $\mathrm{N}_{2}$ adsorption-desorption isotherms at $77 \mathrm{~K}$ are summarized in Table 2. The $\mathrm{N}_{2}$ adsorption-desorption isotherms images are shown in Figs. S2, S3, and S4. It can be seen that the surface area, pore volume, and pore diameter of the catalyst slightly decreased after modification. However, after $\mathrm{Ru}$ was loaded on, the surface area and total pore volume of catalysts increased while the average pore diameter decreased. This may be due to the fact that the reduction process slightly broke the surface of the catalyst and generated some micropores. From the $\mathrm{N}_{2}$ adsorption-desorption isotherms images, all the catalysts exhibit Type IV isotherms with hysteresis loops, which are $\mathrm{H}_{2}$-type in the $P / P_{\mathrm{o}}$ range from 0.44 to 1.0 . The hysteresis loops might be attributed to the capillary condensation within the mesopores, and the long $P / P_{\mathrm{o}}$ range indicated an uneven pore diameter distribution (Bjelić et al. 2019). In summary, the modification had little effect on the textural properties of the catalyst. 
Table 1. The Desorption of $\mathrm{NH}_{3}$

\begin{tabular}{|c|c|c|c|c|}
\hline Entry & $\mathrm{NH}_{3}-\mathrm{TPD}$ & $\begin{array}{c}\text { Peak1 }\left({ }^{\circ} \mathrm{C}\right) \\
\left(\mu \mathrm{mol} \cdot \mathrm{g}^{-1}\right)\end{array}$ & $\begin{array}{c}\text { Peak2 }\left({ }^{\circ} \mathrm{C}\right) \\
\left(\mu \mathrm{mol} \cdot \mathrm{g}^{-1}\right)\end{array}$ & $\begin{array}{c}\text { Peak3 }\left({ }^{\circ} \mathrm{C}\right) \\
\left(\mu \mathrm{mol} \cdot \mathrm{g}^{-1}\right)\end{array}$ \\
\hline 1 & $\mathrm{Sn}-\mathrm{AlOx}$ & $205^{\mathrm{a}}\left(381.90^{\mathrm{b}}\right)$ & $550(346.31)$ & - \\
\hline 2 & $\mathrm{~W} / \mathrm{Sn}-\mathrm{AlOx}$ & $220(320.76)$ & $560(380.61)$ & $950(28.17)$ \\
\hline 3 & $\mathrm{Ru}-\mathrm{W} / \mathrm{Sn}-\mathrm{AlOx}$ & $240(475.11)$ & $560(548.09)$ & - \\
\hline $\begin{array}{l}\text { a Desorbed temperature of the peak } \\
\text { b Amount of the desorbed } \mathrm{NH}_{3}\end{array}$ & \\
\hline
\end{tabular}

Table 2. The Surface Properties of the Catalysts

\begin{tabular}{|c|c|c|c|c|}
\hline Entry & Catalysts & $\begin{array}{c}\text { BET Surface } \\
\text { Area }\left(\mathrm{m}^{2} / \mathrm{g}\right)\end{array}$ & $\begin{array}{c}\text { Total Pore } \\
\text { Volume }\left(\mathrm{cm}^{3} / \mathrm{g}\right)^{\mathrm{a}}\end{array}$ & $\begin{array}{c}\text { Barrett-Joyner-Halenda } \\
(\mathrm{BJH}) \text { Adsorption Average } \\
\text { Pore Diameter }(\AA)\end{array}$ \\
\hline 1 & Sn-AlOx & 157.01 & 0.2906 & 85.05 \\
\hline 2 & W/Sn-AlOx & 139.39 & 0.2288 & 82.98 \\
\hline 3 & Ru-W/Sn-AlOx & 147.36 & 0.2457 & 73.49 \\
\hline \multicolumn{2}{|l}{ a Determined from the amount adsorbed at P/P0 0.95} \\
\hline
\end{tabular}

The XPS results for the elements, such as $\mathrm{Sn}, \mathrm{Al}, \mathrm{Ru}$, and $\mathrm{W}$, from $\mathrm{Sn}-\mathrm{AlOx}, \mathrm{W} / \mathrm{Sn}$ AlOx, Ru/Sn- AlOx, and Ru-W/Sn- AlOx are presented in Fig. S5. From Fig. S5 it can be seen that Sn3d shifted negatively, while Al2p shifted positively when Ru and W were loaded on Sn-AlOx. This was related to the higher electronegativity of Sn than Al, and there was an interaction between $\mathrm{Ru}, \mathrm{W}$, and $\mathrm{Sn}-\mathrm{AlOx}$. In addition to the shift of $\mathrm{Sn3d}$ and A12p, the shift of Ru3d and W4f also appeared when both Ru and W were loaded on SnAlOx. These findings showed that $\mathrm{Ru}$ and $\mathrm{W}$ also interacted with each other. So, Sn, $\mathrm{Al}$, $\mathrm{Ru}$, and $\mathrm{W}$ were not simply stacked together; they had a synergistic effect.

The metal dispersions for the $\mathrm{Ru}, \mathrm{Al}, \mathrm{Sn}$, and $\mathrm{W}$ of the catalyst (Ru-W/Sn- AlOx) were demonstrated by the high-resolution transmission electron microscope (HRTEM) images in Fig. S6. Figure S6 clearly shows that the Ru species was well dispersed on the Sn-AlOx surface, which insured sufficient exposure of the active sites of $\mathrm{Ru}$.

\section{Effects of Catalyst Component}

The results are shown in Table 3. Considering the result in Table 1 and the entries 1,3 , and 6 in Table 3, the yield of PE-soluble products and the strength of acid sites had a positive correlation. This correlation was more conspicuous at $270{ }^{\circ} \mathrm{C}$ (shown in entries 2 and 5). Stronger acid benefited the formation of small molecular products. From entries 1 , 3 , and 6 , it can be seen that the yield of liquid products increased, and solid products decreased with the appearance of hydrogenation component $(\mathrm{Ru})$. The above conclusions were based on the reaction time of $1 \mathrm{~h}$. When the reaction time was $12 \mathrm{~h}$, the main factor influencing the yield was the appearance of the hydrogenation component $(\mathrm{Ru})$ (entries 4 and 7). The acid could still increase the yield of PE-soluble products, but the increase was relatively small (entry 7, 46.99\% compared with entry 4, 36.80\%). In conclusion, acid enhanced the process of lignin depolymerization to monomers or dimers, but it also polymerized more oligomers to solid products (char). The hydrogenation component could effectively stabilize the intermediates and reduce the char formation. From the results, the monomers and dimers were more stable than the oligomers under mild conditions. Therefore, the catalytic effect of the hydrogenation component was not obvious in the short reaction time ( $1 \mathrm{~h}$, entries 3 and 6) or at low temperature $\left(270{ }^{\circ} \mathrm{C}\right.$, entries 2 and 5). From entries 1 and 7, Ru had a synergistic effect with $\mathrm{W}$ for more PE-soluble products, which 
was clearly confirmed by the XPS results of the catalysts (Fig. S5). The yield of total monomers was between $1 / 4$ and $1 / 3$ of the PE-soluble product; details of the monomer product distribution are shown in Table S5. According to Jiang et al. (2016), the $M_{\mathrm{n}}$ of the PE-soluble product is about 364, and the main product of it is dimers. Comparing the blank test, entry 8 , and other results, it was clear that the catalyst had obvious effect on lignin depolymerization. Notably, from entries 1, 3, and 8, the solid acid enhanced the depolymerization and repolymerization, so the char formation and yield of PE-soluble product both increased. From the depolymerization results, it was found that the main influence factors were the catalyst component and the acidity of the catalyst. The other factors, such as textural properties and surface morphology, had little influence.

Table 3. The Effect of Catalyst Component

\begin{tabular}{|c|c|c|c|c|c|c|c|c|}
\hline Entry & Catalyst & $\begin{array}{c}\text { Reaction } \\
\text { Time } \\
\text { (h) }\end{array}$ & $\begin{array}{c}\text { Reaction } \\
\text { Temp. } \\
\left({ }^{\circ} \mathrm{C}\right)\end{array}$ & $\begin{array}{l}\text { Solid } \\
\text { Pro- } \\
\text { duct } \\
(\%)\end{array}$ & $\begin{array}{l}\text { Gas } \\
\text { Pro- } \\
\text { duct } \\
(\%)\end{array}$ & $\begin{array}{l}\text { Liquid } \\
\text { Product } \\
\text { (\%) }\end{array}$ & $\begin{array}{c}\text { PE- } \\
\text { soluble } \\
\text { Product } \\
(\%)\end{array}$ & $\begin{array}{c}\text { Total } \\
\text { Monomers } \\
(\%)\end{array}$ \\
\hline 1 & Sn-AlOx & 1 & 300 & 44.51 & 2.73 & 52.76 & 14.93 & 5.97 \\
\hline 2 & $\begin{array}{l}\text { W/Sn- } \\
\text { AlOx }\end{array}$ & 1 & $270^{a}$ & 9.90 & 1.26 & 88.84 & 12.44 & 4.62 \\
\hline 3 & $\begin{array}{l}\text { W/Sn- } \\
\text { AlOx }\end{array}$ & 1 & 300 & 46.84 & 2.26 & 50.90 & 21.10 & 7.81 \\
\hline 4 & $\begin{array}{l}\text { W/Sn- } \\
\text { AlOx }\end{array}$ & $12^{b}$ & 300 & 30.91 & 4.01 & 65.08 & 36.80 & 14.78 \\
\hline 5 & $\begin{array}{c}\text { Ru- } \\
\text { W/Sn- } \\
\text { AlOx }\end{array}$ & 1 & $270^{a}$ & 7.36 & 1.14 & 91.5 & 9.24 & 4.91 \\
\hline 6 & $\begin{array}{l}\text { Ru- } \\
\text { W/Sn- } \\
\text { AlOx }\end{array}$ & 1 & 300 & 33.14 & 2.95 & 63.91 & 20.19 & 7.48 \\
\hline 7 & $\begin{array}{c}\text { Ru- } \\
\text { W/Sn- } \\
\text { AlOx }\end{array}$ & $12^{b}$ & 300 & 1.92 & 3.76 & 94.32 & 59.86 & 15.69 \\
\hline 8 & $\begin{array}{c}\text { No } \\
\text { catalyst }\end{array}$ & 1 & 300 & 41.73 & 2.21 & 56.06 & 10.11 & 4.13 \\
\hline
\end{tabular}

a: Take $270^{\circ} \mathrm{C}$ as a representative to study the effect of catalyst depolymerization at low temperature.

b: Take $12 \mathrm{~h}$ as an example to study the effect of catalyst depolymerization for a long time.

\section{Effects of Hydrogenation Component}

To research the effects of the hydrogenation component of the catalyst, different noble metals ( $\mathrm{Ru}, \mathrm{Pt}, \mathrm{Pd}$, or $\mathrm{Rh}$ ) and non-noble metals (Ni) were investigated. After the metal was loaded on W/Sn-AlOx, the reactions were recorded at $300{ }^{\circ} \mathrm{C}$ and the reaction time was $12 \mathrm{~h}$. The results are shown in Table 4 . As shown, the noble metals had similar high yield of liquid product and PE-soluble product. From entries 1 to 4, the yield of liquid product was all approximately 94\%. Among them, Ru-W/Sn-AlOx had the best effect of stabilizing the depolymerization intermediate and achieved the highest yield of PE-soluble product $(59.86 \%)$ and monomers $(15.69 \%)$. As known in part "effect of catalyst component", a possible explanation was that Ru has a synergistic effect with W/Sn-AlOx and the effect enhanced the hydrogenation capacity. Compared with the noble metals, Ni resulted in a relatively lower yield of liquid product and PE-soluble product. However, 
from entries 3 through 5, Ni obtained a similar yield of monomers with $\mathrm{Rh}$ and $\mathrm{Pd}$. This indeed showed that $\mathrm{Ni}$ had good capacity to promote depolymerization and get more monomers, but it was relatively weak in hydrogenation. In total, as a non-noble metal, $\mathrm{Ni}$ still needed to be explored.

Table 4. The Effect of Hydrogenation Components

\begin{tabular}{|c|c|c|c|c|c|c|}
\hline Entry & Catalyst & $\begin{array}{c}\text { Solid } \\
\text { Product } \\
(\%)\end{array}$ & $\begin{array}{c}\text { Gas } \\
\text { Product } \\
(\%)\end{array}$ & $\begin{array}{c}\text { Liquid } \\
\text { Product } \\
(\%)\end{array}$ & $\begin{array}{c}\text { PE-soluble } \\
\text { Product } \\
(\%)\end{array}$ & $\begin{array}{c}\text { Total } \\
\text { Monomers } \\
(\%)\end{array}$ \\
\hline 1 & Ru-W/Sn-AIOx & 1.92 & 3.76 & 94.32 & 59.86 & 15.69 \\
\hline 2 & $\mathrm{Pt}-\mathrm{W} / \mathrm{Sn}-\mathrm{AlOx}$ & 1.73 & 3.52 & 94.75 & 55.97 & 14.43 \\
\hline 3 & $\mathrm{Pd}-\mathrm{W} / \mathrm{Sn}-\mathrm{AlOx}$ & 2.58 & 4.03 & 93.39 & 56.19 & 13.79 \\
\hline 4 & $\mathrm{Rh}-\mathrm{W} / \mathrm{Sn}-\mathrm{AlOx}$ & 1.37 & 3.12 & 95.51 & 52.71 & 12.78 \\
\hline 5 & $\mathrm{Ni}-\mathrm{W} / \mathrm{Sn}$-AlOx & 11.76 & 3.19 & 85.05 & 48.86 & 13.69 \\
\hline
\end{tabular}

\section{Effects of Reaction Temperature and Time}

To study the effects of reaction temperature and time, the lignin depolymerization reactions were performed at different temperatures $\left(270,290,300\right.$, and $\left.310^{\circ} \mathrm{C}\right)$ and various reaction times $(1,3,6$, and $12 \mathrm{~h})$ using $\mathrm{Ru}-\mathrm{W} / \mathrm{Sn}-\mathrm{AlOx}$ as catalyst. In addition, the whole results are shown in Table S6. The data of different temperatures with $12 \mathrm{~h}$ reaction and the data of various reaction times at $300{ }^{\circ} \mathrm{C}$ are shown in Figs. 2 and 3. As shown in Fig. 2 , the yield of liquid product decreased from $94.81 \%$ to $67.82 \%$ when the temperature increased from 270 to $290{ }^{\circ} \mathrm{C}$. This may be attributed to the relatively low hydrogenation ability at the mild conditions. Then the yield increased to $95.28 \%$ at $310{ }^{\circ} \mathrm{C}$. This indeed revealed the effect of the hydrogenation component.

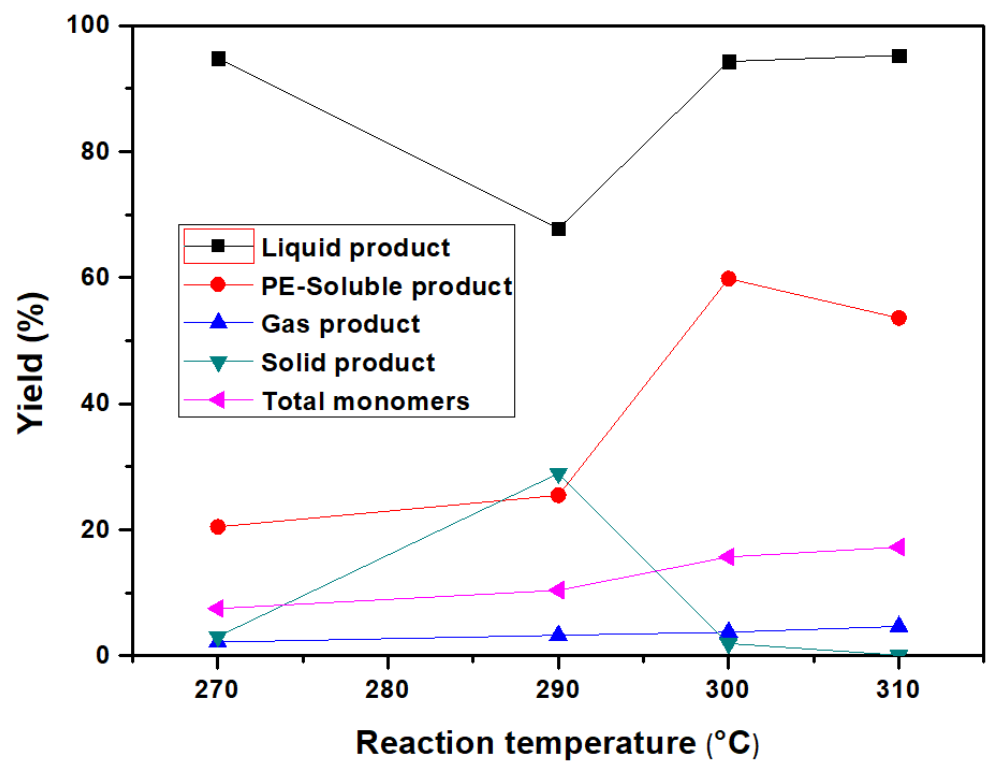

Fig. 2. Product distribution with different temperature; conditions: $0.5 \mathrm{~g}$ lignin, $0.1 \mathrm{~g}$ catalyst, $12 \mathrm{~h}$, $2 \mathrm{MPa} \mathrm{H}_{2}$, and $900 \mathrm{rpm}$ 


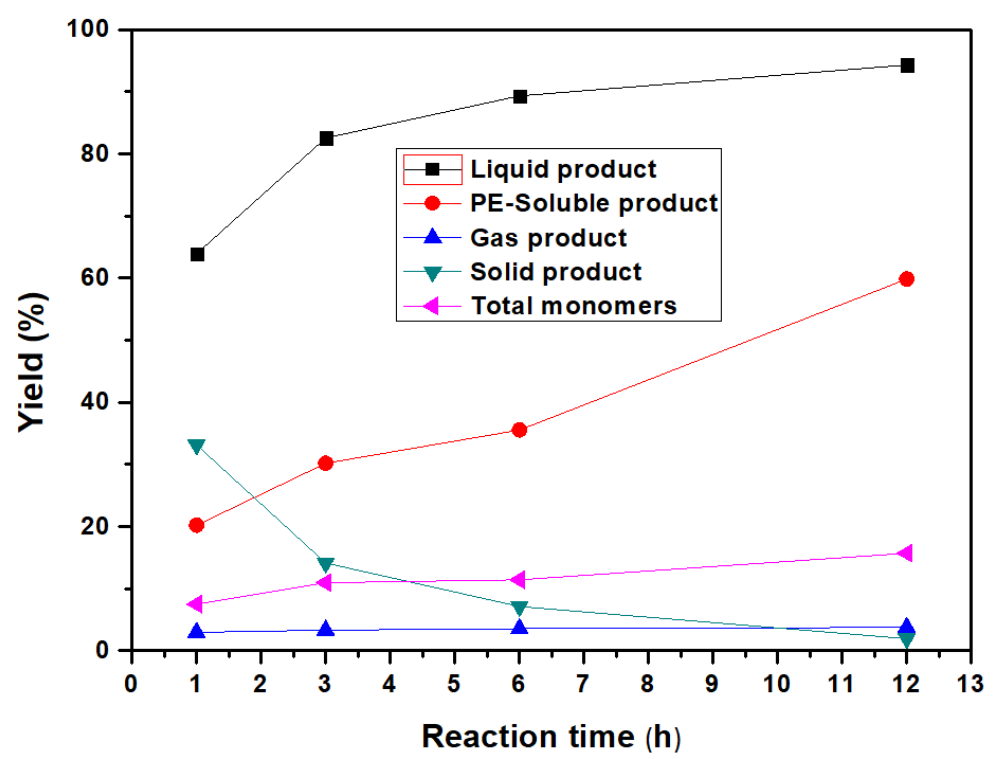

Fig. 3. Product distribution with different reaction time; conditions: $0.5 \mathrm{~g}$ lignin, $0.1 \mathrm{~g}$ catalyst, 300 ${ }^{\circ} \mathrm{C}, 2 \mathrm{MPa} \mathrm{H}_{2}$, and $900 \mathrm{rpm}$

The yield of PE-soluble product first increased from $270{ }^{\circ} \mathrm{C}(20.47 \%)$, then reached the top at $300{ }^{\circ} \mathrm{C}(59.86 \%)$, and then declined $\left(53.58 \%, 310{ }^{\circ} \mathrm{C}\right)$. This demonstrated that excessive temperature would increase the repolymerization and reduce the yield of PEsoluble product. Different from the PE-soluble product, the yield of total monomers increased from $7.49 \%$ to $17.22 \%$ with the rising of temperature. This also indicated that the formed monomers were more stable than the PE-soluble product, mostly the dimers.

Reaction time is also an important factor for lignin depolymerization. The results of different reaction time at $300{ }^{\circ} \mathrm{C}$ are shown in Fig. 3. The yield of liquid product rose rapidly from $63.91 \%(1 \mathrm{~h})$ to $82.57 \%(3 \mathrm{~h})$ and then increased relatively slowly to $94.32 \%$ $(12 \mathrm{~h})$. The trend of solid product was just the reverse. The char yield declined from $33.14 \%$ $(1 \mathrm{~h})$ to $14.11 \%(3 \mathrm{~h})$ fast and then slowly decreased to $1.92 \%(12 \mathrm{~h})$. The yield of gas product, PE-soluble product and total monomers increased steadily from $2.95 \%, 20.19 \%$, and $7.48 \%$ ( $1 \mathrm{~h}$ ) to $3.76 \%, 59.86 \%$, and $15.69 \%$ (12 h). In conclusion, at a proper high temperature $\left(300{ }^{\circ} \mathrm{C}\right)$, prolonging reaction time could improve lignin depolymerization a lot.

\section{The Analysis of Liquid Products}

From the GC-MS and GC analyses, the monomers that could be quantified were phenol, 2-methoxyphenol, veratrole, 4-ethylphenol, 4-methylguaiacol, 3,4-dimethoxytoluene, 4-ethylguaiacol, syringol, eugenol, 4-propylguaiacol, vanillina, isoeugenol, acetovanillone, 2,6-di-tert-butyl-4-methylphenol, 4-hydroxyl-3-methoxypropiophenone, and homovanillic acid. The reason that other products could not be quantified was that there were too many possible structural formulas and some of the standard samples could not be purchased. The results of the monomers are demonstrated in Figs. 4 and 5. The whole details are shown in Table S7. To explain the results better, the yield of the guaiacol, 4-methyl-guaiacol, 4-ethyl-guaiacol, 4-propyl-guaiacol, and the yield of veratrole, 3,4dimethoxytoluene, and syringol were summed and named as the yield of the guaiacols and dimethoxy products. From Fig. 4, the yield of the guaiacols first increased from $2.4 \%$ (270 $\left.{ }^{\circ} \mathrm{C}\right)$ to $4.92 \%\left(290{ }^{\circ} \mathrm{C}\right)$ and then decreased to $4.26 \%\left(310{ }^{\circ} \mathrm{C}\right)$. This phenomenon could be 
explained based on a hypothesis that the guaiacols were converted to the corresponding dimethoxy products at high temperature due to the yield of dimethoxy products increasing from $0.04 \%\left(270{ }^{\circ} \mathrm{C}\right)$ to $0.39 \%\left(310{ }^{\circ} \mathrm{C}\right)$. In Fig. 4 , the yields of total identified, total unquantifiable, and total monomers increased respectively from $5.46 \%, 2.03 \%$, and $7.49 \%$ to $8.27 \%, 8.96 \%$, and $17.22 \%$ along with rising temperature. It is worth mentioning that the yield of total unquantifiable monomers increased rapidly from 290 to $300{ }^{\circ} \mathrm{C}(2.91 \%$ to $7.6 \%$ ). This indicated that the reaction reached a more violent stage when the temperature was $300{ }^{\circ} \mathrm{C}$ and many unquantifiable complex products were formed. Because the dimethoxy products increased along with the rising temperature, these unquantifiable products might include many dimethoxy products.

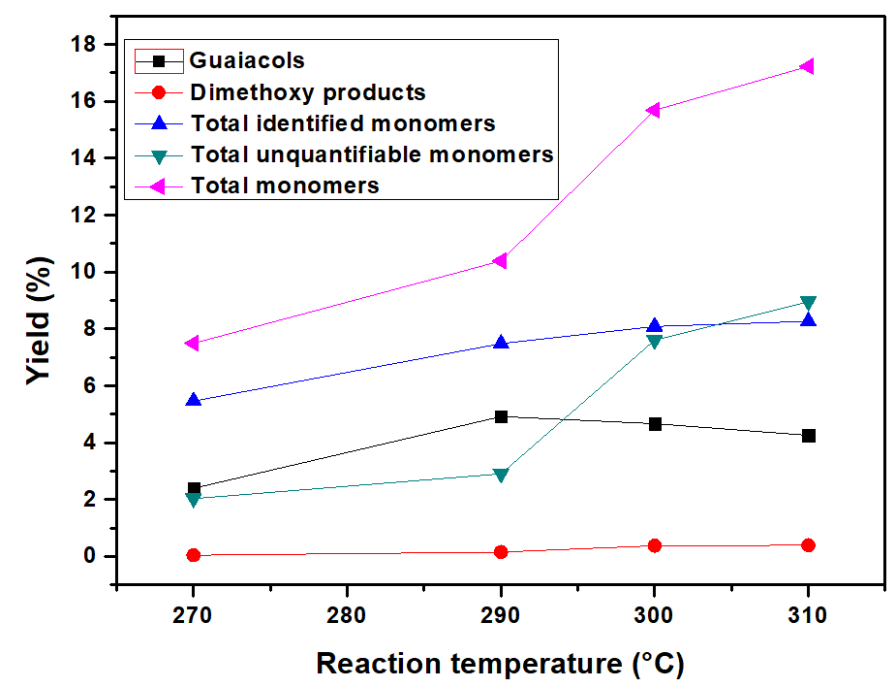

Fig. 4. Distribution of monomers at different temperature; conditions: $0.5 \mathrm{~g}$ lignin, $0.1 \mathrm{~g}$ catalyst, $12 \mathrm{~h}, 2 \mathrm{MPa} \mathrm{H}$, and $900 \mathrm{rpm}$

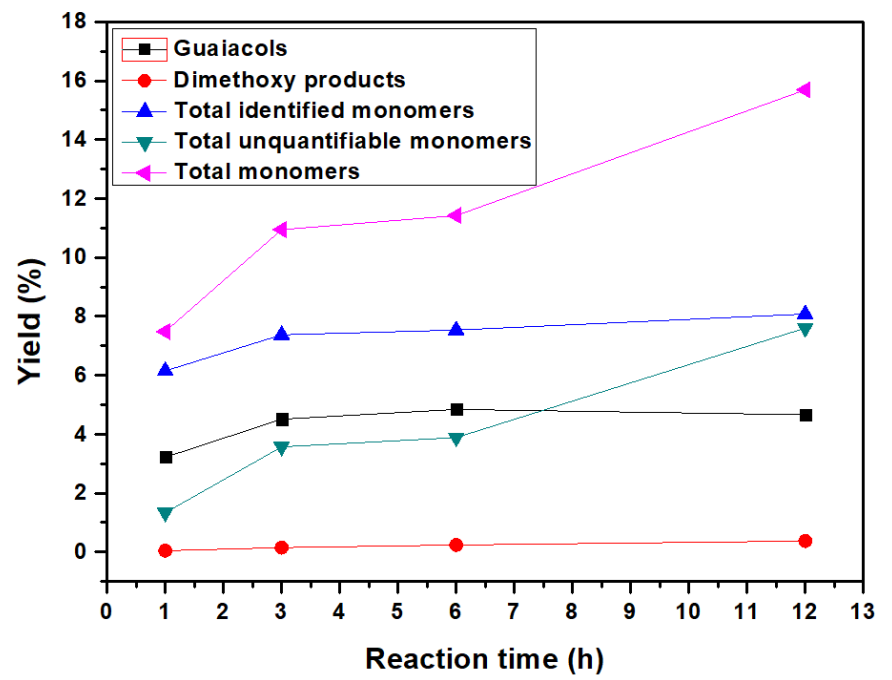

Fig. 5. Distribution of yield of monomers with various reaction times; conditions: $0.5 \mathrm{~g}$ lignin, $0.1 \mathrm{~g}$ catalyst, $300^{\circ} \mathrm{C}, 2 \mathrm{MPa} \mathrm{H}_{2}$, and $900 \mathrm{rpm}$ 
Figure 5 demonstrates a similar trend to Fig. 4. The yields of total identified, total unquantifiable, and total monomers increased respectively from $6.15 \%, 1.33 \%$, and $7.48 \%$ to $8.08 \%, 7.6 \%$, and $15.69 \%$ with prolonging the reaction time. The change rules of the yields of the guaiacols and dimethoxy products were also similar. The yield of the guaiacols first increased from $3.22 \%(1 \mathrm{~h})$ to $4.84 \%(6 \mathrm{~h})$, and then decreased to $4.66 \%(12 \mathrm{~h})$ and the yield of dimethoxy products increased from $0.05 \%(1 \mathrm{~h})$ to $0.37 \%(12 \mathrm{~h})$. This illustrated that prolonging the reaction time vastly benefited the formation of monomers and the elimination of chars. The reason may be that hydrogenation was a relatively slower process than acid catalytic depolymerization and it needed more reaction time. In summary, $300{ }^{\circ} \mathrm{C}$ is an appropriate temperature for lignin depolymerization with $\mathrm{Ru}-\mathrm{W} / \mathrm{Sn}-\mathrm{AlO}_{\mathrm{x}}$ and a long reaction time (at least $12 \mathrm{~h}$ ) greatly benefits lignin depolymerization. Moreover, the guaiacols could be converted to corresponding dimethoxy products under harsh conditions.

Figure 6 shows the 2D HSQC NMR spectrum of the liquid product obtained by depolymerizing lignin at 260 and $300{ }^{\circ} \mathrm{C}$. The authors have reported that the $\beta-\mathrm{O}-4$ bond is the main link unit in the structure of the original lignin, accompanied by some $\beta-5$ and $\beta$ - $\beta$ link units (Dou et al. 2019). Comparing these spectra, with the disappearance of $\beta$-O$4, \beta-5$ and $\beta-\beta$ linkage units, the side chains and aromatic structures were extensively changed. The catalyst broke the $\mathrm{C}-\mathrm{O}-\mathrm{C}$ bond and $\mathrm{C}-\mathrm{C}$ link by polarizing the $\mathrm{C}-\mathrm{O}$ and $\mathrm{C}-\mathrm{C}$ bonds, thereby effectively depolymerizing lignin. However, a small amount of signal peaks for dihydroconiferyl alcohol (M) were still present. At the maximum temperature of 300 ${ }^{\circ} \mathrm{C}$ for $12 \mathrm{~h}$, almost all the side chains in the saturated aliphatic hydrocarbon region were converted to saturated structures. The results illustrated that kraft lignin could be efficiently converted to small molecular substances after high temperature and long depolymerization reactions.
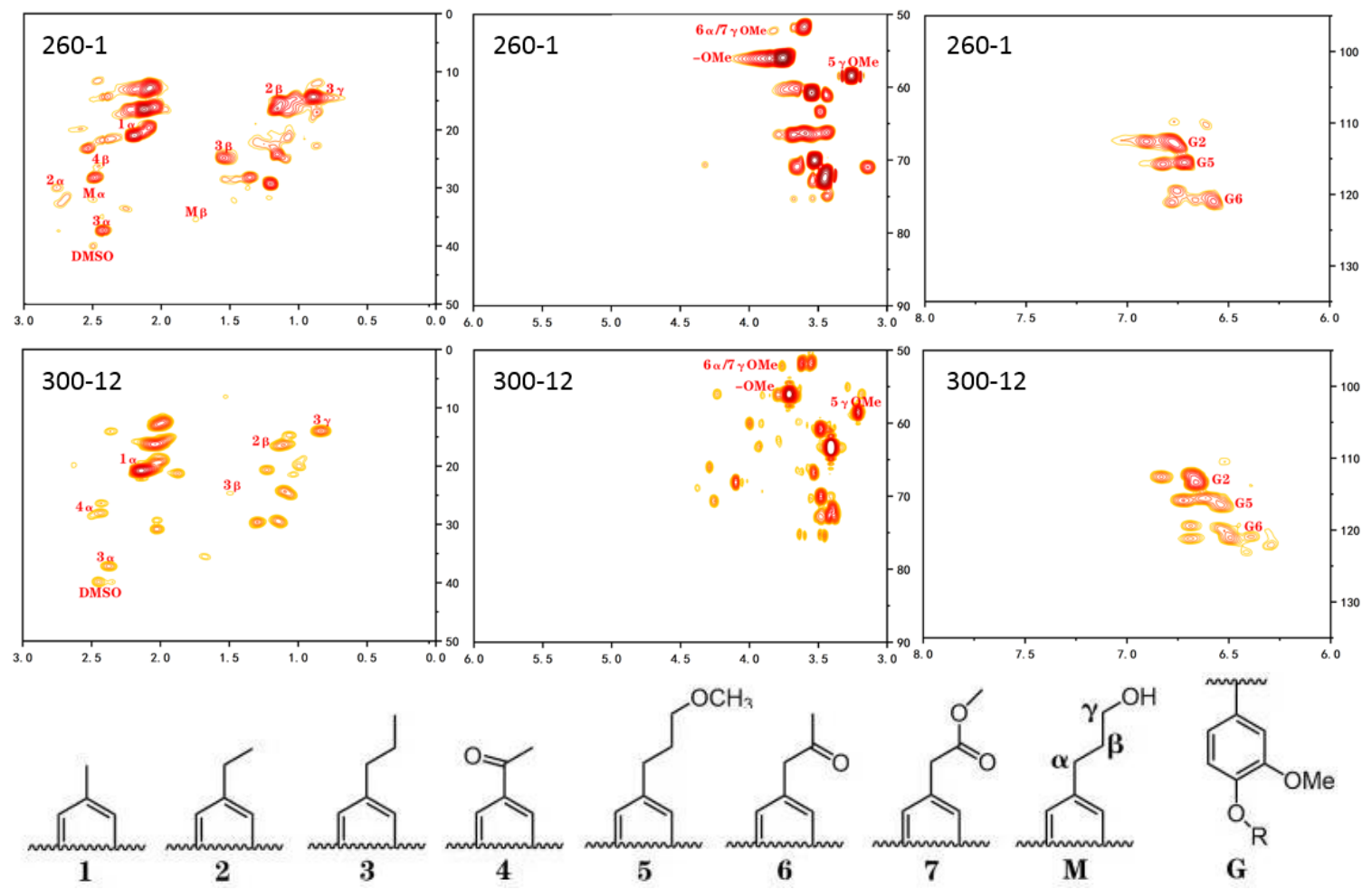

Fig. 6. 2D HSQC NMR spectra of the liquid yield fractions 
Gel permeation chromatography (GPC) was used to determine the molecular weight distribution of degradation products and original kraft lignin (Fig. 7 and Table 7). The depolymerized product was mainly composed of monomer $(100 \mathrm{~g} / \mathrm{mol}-250 \mathrm{~g} / \mathrm{mol})$, dimer $(250$ to $500 \mathrm{~g} / \mathrm{mol})$, trimer $(500 \mathrm{~g} / \mathrm{mol}$ to $650 \mathrm{~g} / \mathrm{mol})$, and oligomer $(>650 \mathrm{~g} / \mathrm{mol})$ (Zhang et al. 2021). Comparing the chromatograms of lignin and depolymerization products, it could be clearly found that the product had undergone extensive degradation. More importantly, the difference in molecular weight between the degradation products reacted at 260 and $300{ }^{\circ} \mathrm{C}$ confirmed that more lignin degradation occurred at high temperature. The weight-average molecular weight of the liquid product at 260 and $300{ }^{\circ} \mathrm{C}$ was 928 and $325 \mathrm{~g} / \mathrm{mol}$, and the dispersion was 2.78 and 2.04, respectively, which was much lower than that of the original kraft lignin $4360 \mathrm{~g} / \mathrm{mol}$ for weight-average molecular weight and 3.39 for dispersion.

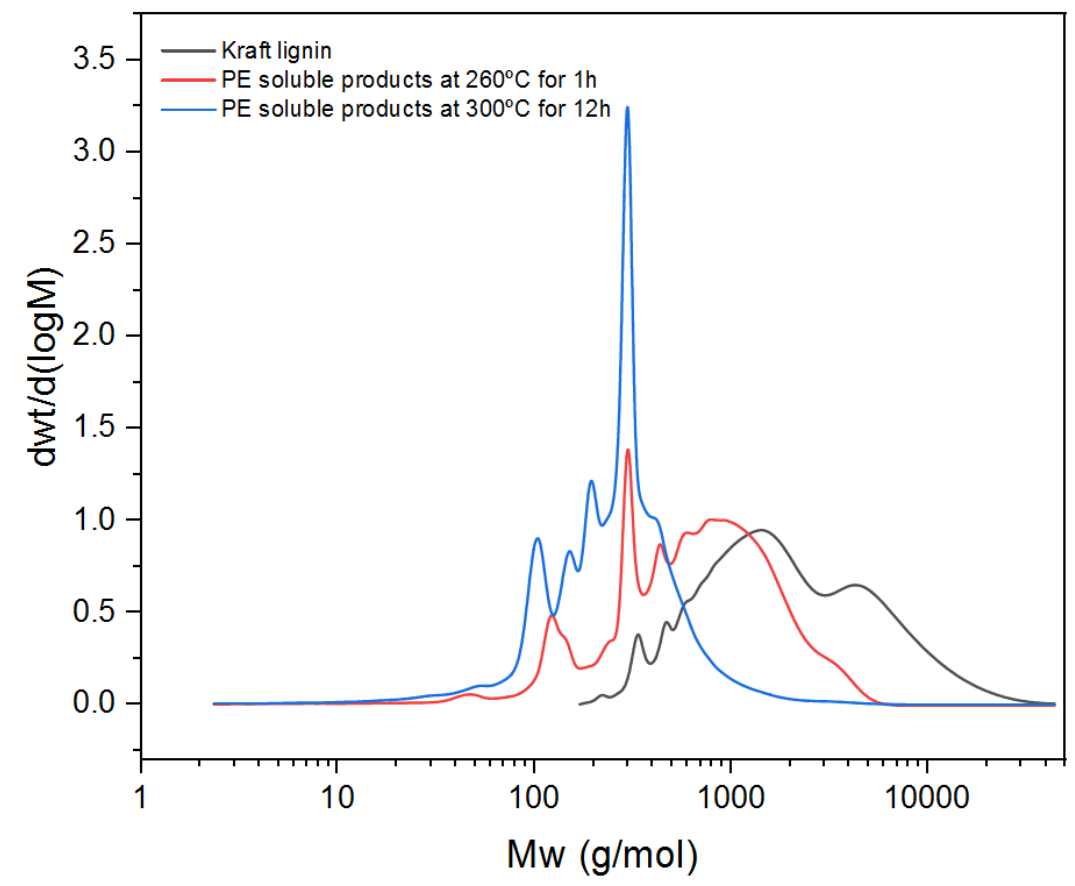

Fig. 7. GPC chromatographs of kraft lignin and the liquid yield fractions

Table 7. The Details of GPC Characterization

\begin{tabular}{|c|c|c|c|}
\hline Sample & $M_{\mathrm{n}}(\mathrm{g} / \mathrm{mol})$ & $M_{\mathrm{w}}(\mathrm{g} / \mathrm{mol})$ & PDI \\
\hline Kraft lignin & 1286 & 4360 & 3.39 \\
\hline $260^{\circ} \mathrm{C}-1 \mathrm{~h}$ & 334 & 928 & 2.78 \\
\hline $300^{\circ} \mathrm{C}-12 \mathrm{~h}$ & 159 & 325 & 2.04 \\
\hline
\end{tabular}

The elemental contents of lignin liquid product are shown in Table 8. As shown in Table 8, after the reaction, the contents of $\mathrm{C}$ and $\mathrm{H}$ increased obviously, while the contents of $\mathrm{O}$ and $\mathrm{S}$ decreased. Therefore the HHV increased. This indeed demonstrated that hydrodeoxygenation was occurring during the depolymerization process. From Table 8, it can be seen that increasing the temperature and prolonging the reaction time would effectively promote the increase of HHV. Meanwhile, as shown from the last two entries of the table, the presence of $\mathrm{Ru}$ could enhance the hydrodeoxygenation. 
Table 8. Elemental Contents of the Liquid Product

\begin{tabular}{|c|c|c|c|c|c|c|c|c|c|}
\hline & \multirow{2}{*}{ Catalyst } & \multirow{2}{*}{$\begin{array}{c}\text { Reaction } \\
\text { Tempera- } \\
\text { ture }\end{array}$} & \multirow{2}{*}{$\begin{array}{l}\text { Reaction } \\
\text { Time }\end{array}$} & \multicolumn{5}{|c|}{ Elemental Content (wt\%) } & \multirow{2}{*}{$\begin{array}{c}\mathrm{HHV} \\
(\mathrm{MJ} / \mathrm{k} \\
\mathrm{g})\end{array}$} \\
\hline & & & & C & $\mathrm{H}$ & $\mathrm{O}$ & $\mathrm{N}$ & $S$ & \\
\hline $\begin{array}{c}\text { Indulin } \\
\text { AT }\end{array}$ & \multicolumn{3}{|c|}{ - } & 65.5 & 5.6 & 25.2 & 0.4 & 3.3 & 25.7 \\
\hline \multirow{4}{*}{$\begin{array}{l}\text { Liquid } \\
\text { Product }\end{array}$} & $\begin{array}{c}\text { Ru-W/Sn- } \\
\text { AlOx }\end{array}$ & $270^{\circ} \mathrm{C}$ & $1 \mathrm{~h}$ & 65.0 & 6.5 & 25.4 & 0.4 & 2.7 & 26.7 \\
\hline & $\begin{array}{l}\text { Ru-W/Sn- } \\
\text { AlOx }\end{array}$ & $300^{\circ} \mathrm{C}$ & $1 \mathrm{~h}$ & 67.0 & 7.0 & 22.8 & 0.4 & 2.8 & 28.5 \\
\hline & $\begin{array}{c}\text { Ru-W/Sn- } \\
\text { AlOx }\end{array}$ & $300^{\circ} \mathrm{C}$ & $12 \mathrm{~h}$ & 74.2 & 7.2 & 15.8 & 0.5 & 2.3 & 32.4 \\
\hline & W/Sn-AlOx & $300^{\circ} \mathrm{C}$ & $12 \mathrm{~h}$ & 69.8 & 7.1 & 19.9 & 0.4 & 2.8 & 30.1 \\
\hline
\end{tabular}

\section{Stability Tests}

To research the reason that the catalyst was deactivated more effectively, two experiments were designed. One experiment was that no lignin was used in the first two cycles and another one was that lignin was used in every cycle. The results of the stability tests are shown in Table 9. In entry 1 and 2, after two cycles used, the property of RuW/Sn-AlOx decreased approximately $20 \%$. Because no lignin was used in the $1^{\text {st }}$ and $2^{\text {nd }}$ cycle, the most possible reason of catalyst deactivation was that active component, $\mathrm{Ru}$, was missing. Therefore, the yield of PE-soluble product decreased, and the char formation increased. The resultant monomers were more stable than the PE-soluble product, mostly the dimers, so the yield of total monomers decreased a little. In entry 3 , because the lignin was used in every cycle, besides the missing of $\mathrm{Ru}$, the acid active sites were covered by the char. The acidity of the catalyst was weakened so the char formation decreased comparing with entry 2. Meanwhile, the yield of PE-soluble product decreased more than entry 2. In total, the stability of $\mathrm{Ru}-\mathrm{W} / \mathrm{Sn}-\mathrm{AlOx}$ was acceptable.

Table 9. Results of the Stability Tests

\begin{tabular}{|c|c|c|c|c|c|c|}
\hline Entry & Catalyst & $\begin{array}{l}\text { Solid } \\
\text { Product } \\
(\%)\end{array}$ & $\begin{array}{c}\text { Gas } \\
\text { Product } \\
(\%)\end{array}$ & $\begin{array}{l}\text { Liquid } \\
\text { Product } \\
(\%)\end{array}$ & $\begin{array}{c}\text { PE- } \\
\text { soluble } \\
\text { Product } \\
(\%)\end{array}$ & $\begin{array}{c}\text { Total } \\
\text { Monomers } \\
(\%)\end{array}$ \\
\hline 1 & $\begin{array}{c}\text { 1st-use Ru-W/Sn- } \\
\text { AlOx }\end{array}$ & 1.92 & 3.76 & 94.32 & 59.86 & 15.69 \\
\hline $2^{\mathrm{a}}$ & $\begin{array}{c}\text { 3rd-use Ru-W/Sn- } \\
\text { AlOx }\end{array}$ & 13.24 & 3.18 & 83.58 & 47.42 & 14.71 \\
\hline $3^{b}$ & $\begin{array}{c}\text { 3rd-use Ru-W/Sn- } \\
\text { AlOx }\end{array}$ & 10.29 & 2.97 & 86.74 & 41.34 & 13.43 \\
\hline
\end{tabular}

\section{Possible Reaction Pathways}

Combining the above analysis results from the catalyst characterization and the generated products, a possible pathway is proposed for kraft lignin depolymerization on the catalyst. The aerobic active center interacts with oxygen atoms and polarizes the $\mathrm{C}-\mathrm{O}$ bond of lignin, which is more obvious at high temperature. Ru can activate the hydrogen 
species, and the activated hydrogen can attack and break the $\mathrm{C}-\mathrm{O}-\mathrm{C}$ and $\mathrm{C}-\mathrm{C}$ bonds on the side chain of lignin to form reactive intermediate fragments, which can further undergo polycondensation to form solid products. The catalyst can passivate the reaction intermediates while depolymerizing, avoiding the formation of a large amount of coking, thereby improving the depolymerization efficiency of lignin.

\section{CONCLUSIONS}

1. In the study of catalyst components, it was shown that the W-modified method effectively enhanced the acidity of the catalyst and the strength of the acid component had positive correlation with the formation of small molecular products. The effects of different catalyst components were more conspicuous at mild conditions such as low temperature $\left(270{ }^{\circ} \mathrm{C}\right)$ and short reaction time $(1 \mathrm{~h})$. The benefit of hydrogenation component became at high temperature $\left(300^{\circ} \mathrm{C}\right)$ and long reaction time $(12 \mathrm{~h})$.

2. $\mathrm{Ru}-\mathrm{W} / \mathrm{Sn}-\mathrm{AlO}_{\mathrm{x}}$ was shown to be an effective catalyst for the lignin depolymerization. At $300{ }^{\circ} \mathrm{C}$ and with $12 \mathrm{~h}$ reaction, it converted about $95 \%$ lignin into liquid product and $2 / 3$ of the liquid product were monomers, dimers, and some oligomers. At $310^{\circ} \mathrm{C}$ and with $12 \mathrm{~h}$ reaction, $17.22 \%$ monomers were achieved. Meanwhile, the catalyst effectively reduced the char to less than $2 \%$.

3. After the catalytic depolymerization, the higher heating value (HHV) of the liquid products was increased from 25.7 to $32.4 \mathrm{MJ} / \mathrm{kg}$. This indeed demonstrated the hydrodeoxygenation ability of the catalyst.

\section{ACKNOWLEDGMENTS}

This study was financially supported by the Education Department of Anhui Province (Grant No. KJ2020A0279), the National Natural Science Foundation of China (Grant No. 51976212), the National Key R\&D Program of China (Grant No. 2018YFB1501601), and the Program of "Transformational Technologies for Clean Energy and Demonstration", Strategic Priority Research Program of the Chinese Academy of Sciences (Grant No. XDA 21060101).

\section{REFERENCES CITED}

Bjelić, A., Grilc, M., Huš, M., and Likozar, B. (2019). "Hydrogenation and hydrodeoxygenation of aromatic lignin monomers over $\mathrm{Cu} / \mathrm{C}, \mathrm{Ni} / \mathrm{C}, \mathrm{Pd} / \mathrm{C}, \mathrm{Pt} / \mathrm{C}, \mathrm{Rh} / \mathrm{C}$ and $\mathrm{Ru} / \mathrm{C}$ catalysts: Mechanisms, reaction micro-kinetic modelling and quantitative structure-activity relationships," Chem. Eng. J. 359, 305-320. DOI: 10.1016/j.cej.2018.11.107

Cai, Q., Yu, T., and Zhang, S. (2020). "Enhanced aromatic hydrocarbon production from bio-oil hydrotreating-cracking by Mo-Ga modified HZSM-5," Fuel 269, article ID 11738. DOI: 10.1016/j.fuel.2020.117386

Dabral, S., Engel, J., Mottweiler, J., Spoehrle, S. S., Lahive, C. W., and Bolm, C. (2018). "Mechanistic studies of base-catalysed lignin depolymerisation in dimethyl 
carbonate," Green Chem. 20(1), 170-182. DOI: 10.1039/c7gc03110f

Das, A., Rahimi, A., Ulbrich, A., Alherech, M., Motagamwala, A. H., Bhalla, A., Sousa, L. D. A., Dumesic, J. A., Hegg, E. L., Dale, B. E., et al. (2018). "Lignin conversion to low-molecular-weight aromatics via an aerobic oxidation-hydrolysis sequence: Comparison of different lignin sources," ACS Sustain. Chem. Eng. 6(3), 3367-3374. DOI: 10.1021/acssuschemeng.7b03541

Dou, X. M., Jiang, X., Li, W. Z., Zhu, C. F., Liu, Q. C., Lu, Q. Zheng, X. S., Chang, M. H., Hasan, J. (2019). "Highly efficient conversion of kraft lignin into liquid fuels with a Co-Zn-beta zeolite catalyst," Appl. Catal. B, 268. DOI:

10.1016/j.apcatb.2019.118429

Guo, H., Li, C., Qi, Z., Liu, Y., Xia, H., Li, L., Huang, Q.T., Wang, A. Q., and Li, C. Z. (2019). "Tungsten-based catalysts for lignin depolymerization: The role of tungsten species in C-O bond cleavage," Catal. Sci. Technol. 9. 2144-2151. DOI: $10.1039 / \mathrm{c} 9 \mathrm{cy} 00251 \mathrm{k}$

Guo, S., Lai, C., Wu, C., Cen, G., Posthuma, D. (2018). "Conversion discriminative analysis on mild cognitive impairment using multiple cortical features from MR images," Front. Aging Neurosci. 9, article no. 146. DOI: 10.3389/fnagi.2017.00146

Heda, J., Niphadkar, P., and Bokade, V. (2019). "Efficient synergetic combination of HUSY and $\mathrm{SnO}_{2}$ for direct conversion of glucose into ethyl levulinate (biofuel additive)," Energ. Fuel. 33(3), 2319-2327. DOI: 10.1021/acs.energyfuels.8b04395

Howell, J., Roesing, M., and Boucher, D. (2017). "A functional approach to solubility parameter computations," J. Phys. Chem. B. 121(16), 4191-4201. DOI:

10.1021/acs.jpcb.7b01537

Hu, X., Nango, K., Bao, L., Li, T., Hasan, M. D. M., and Li, C. (2019). "High yields of solid carbonaceous materials from biomass," Green Chem. 21(5), 1128-1140. DOI: $10.1039 / \mathrm{c} 8 \mathrm{gc} 03153 \mathrm{c}$

Jiang, S., Hu, X., Wu, L., Zhang, L., Wang, S., Li, T., and Li, C. Z. (2018). "Reaction behaviour of light and heavy components of bio-oil in methanol and in water," Fuel 232, 645-652. DOI: 10.1016/j.fuel.2018.06.015

Jiang, X., Savithri, D., and Du, X. (2016). "Fractionation and characterization of kraft lignin by sequential precipitation with various organic solvents," ACS Sustainable Chemistry \& Engineering 5(1), 835-842. DOI: 10.1021/acssuschemeng.6b02174

Jiang, Z., He, T., Li, J., and Hu, C. (2014). "Selective conversion of lignin in corncob residue to monophenols with high yield and selectivity," Green Chem. 16(9), 42574265. DOI: $10.1039 / \mathrm{c} 4 \mathrm{gc00620h}$

Jindal, M. K., and Jha, M. K. (2016). "Effect of process parameters on hydrothermal liquefaction of waste furniture sawdust for bio-oil production," RSC $A d v$. 6(48), 41772-41780. DOI: $10.1039 / \mathrm{c} 6 \mathrm{ra02868c}$

Kloekhorst, A., and Heeres, H. J. (2016). "Catalytic hydrotreatment of alcell lignin fractions using a Ru/C catalyst," Catal. Sci. Technol. 6(19), 7053-7067. DOI: 10.1039/c6cy00523c

Kurmach, M. M., Popovych, N. O., Kyriienko, P. I., Yaremov, P. S., Khyzhun, O. Y., Andreev, O. V., and Shvets, O. V. (2019). "Effect of production conditions of hierarchical SnAl-BEA zeolites on their acidity and catalytic activity in tandem process for the production of 4-methoxybenzyl-sec-butyl ether," Theor. Exp. Chem. 55, 56-63. DOI: 10.1007/s11237-019-09596-4 
Levin, I., and Brandon, D. (1998). "Metastable alumina polymorphs: Crystal structures and transition sequences," J. Am. Ceram. Soc. 81(8), 1995-2012. DOI: 10.1111/j.1151-2916.1998.tb02581.x

Li, P., Chen, I., and Penner-Hahn, J. E. (1994). "Effect of dopants on zirconia stabilization-An X-ray absorption study: I, trivalent dopants," J. Am. Ceram. Soc. 77(1), 118-128. DOI: 10.1111/j.1151-2916.1994.tb06964.X

Liao, Y., Liu, Q., Wang, T., Long, J., Ma, L., and Zhang, Q. (2014). “Zirconium phosphate combined with $\mathrm{Ru} / \mathrm{C}$ as a highly efficient catalyst for the direct transformation of cellulose to C-6 alditols," Green Chem. 16(6), 3305-3312. DOI: $10.1039 / \mathrm{c} 3 \mathrm{gc} 42444 \mathrm{~h}$

Limarta, S. O., Ha, J., Park, Y., Lee, H., Suh, D. J., and Jae, J. (2018). “Efficient depolymerization of lignin in supercritical ethanol by a combination of metal and base catalysts," Ind. Eng. Chem. 57, 45-54. DOI: 10.1016/j.jiec.2017.08.006

Lin, H., Chen, J., Zhao, Y., and Wang, S. (2017a). "Conversion of C5 carbohydrates into furfural catalyzed by $\mathrm{SO}_{3} \mathrm{H}$-functionalized ionic liquid in renewable gammavalerolactone," Energ. Fuel. 31(4), 3929-3934. DOI: 10.1021/acs.energyfuels.6b01975

Lin, H., Xiong, Q., Zhao, Y., Chen, J., and Wang, S. (2017b). “Conversion of carbohydrates into 5-hydroxymethylfurfural in a green reaction system of $\mathrm{CO}_{2}$-waterisopropanol," AIChE J. 63(1), 257-265. DOI: 10.1002/aic.15550

Liu, C., Wu, S., Zhang, H., and Xiao, R. (2019). "Catalytic oxidation of lignin to valuable biomass-based platform chemicals: A review," Fuel Process Technol. 191, 181-201. DOI: 10.1016/j.fuproc.2019.04.007

Liu, Y., Chen, L., Wang, T., Zhang, Q., Wang, C., Yan, J., and Ma, L. (2015). “One-pot catalytic conversion of raw lignocellulosic biomass into gasoline alkanes and chemicals over $\mathrm{LiTaMoO}_{6}$ and $\mathrm{Ru} / \mathrm{C}$ in aqueous phosphoric acid," ACS Sustain. Chem. Eng. 3(8), 1745-1755. DOI: 10.1021/acssuschemeng.5b00256

Long, J., Xu, Y., Wang, T., Yuan, Z., Shu, R., Zhang, Q., and Ma, L. (2015). 'Efficient base-catalyzed decomposition and in situ hydrogenolysis process for lignin depolymerization and char elimination," Appl. Energ. 141, 70-79. DOI: 10.1016/j.apenergy.2014.12.025

Ma, D., Lu, S., Liu, X., Guo, Y., and Wang, Y. (2019a). "Depolymerization and hydrodeoxygenation of lignin to aromatic hydrocarbons with a Ru catalyst on a variety of Nb-based supports," Chinese J. Catal. 40(4), 609-617. DOI:

10.1016/S1872-2067(19)63317-6

Ma, H., Li, H., Zhao, W., Li, L., Liu, S., Long, J., and Li, X. (2019b). "Selective depolymerization of lignin catalyzed by nickel supported on zirconium phosphate," Green Chem. 21(3), 658-668. DOI: 10.1039/c8gc03617a

Ma, Z., Wang, J., Li, C., Yang, Y., Liu, X., Zhao, C., and Chen, D. (2019c). "New sight on the lignin torrefaction pretreatment: Relevance between the evolution of chemical structure and the properties of torrefied gaseous, liquid, and solid products," Bioresource Technol. 288, article ID 121528. DOI: 10.1016/j.biortech.2019.121528

Rahimi, A., Ulbrich, A., Coon, J. J., and Stahl, S. S. (2014). "Formic-acid-induced depolymerization of oxidized lignin to aromatics," Nature 515, 249-252. DOI: 10.1038/nature 13867

Rasmussen, M. J., and Medlin, J. W. (2020). "Role of tungsten modifiers in bimetallic catalysts for enhanced hydrodeoxygenation activity and selectivity," Catal. Sci. Technol. 10, 414-4233.10. DOI: 10.1039/c9cy02240f. 
Rinaldi, R., Jastrzebski, R., Clough, M. T., Ralph, J., Kennema, M., Bruijnincx, P. C. A., and Weckhuysen, B. M. (2016). "Paving the way for lignin valorisation: Recent advances in bioengineering, biorefining and catalysis," Angew. Chem. Int. Ed. Engl. 55(29), 8164-8215. DOI: 10.1002/anie.201510351

Sá, J., Gasparovicova, D., Hayek, K., Halwax, E., Anderson, J. A., and Vinek, H. (2005). "Water denitration over a $\mathrm{Pd}-\mathrm{Sn} / \mathrm{Al}_{2} \mathrm{O}_{3}$ catalyst," Catal. Lett. 105, 209-217. DOI: $10.1007 / \mathrm{s} 10562-005-8692-7$

Shao, Y., Xia, Q., Dong, L., Liu, X., Han, X., Parker, S. F., Cheng, Y., Daemen, L. L., Ramirez-Cuesta, A. J., Yang, S., et al. (2017). "Selective production of arenes via direct lignin upgrading over a niobium-based catalyst," Nat. Commun. 8, article no. 16104. DOI: $10.1038 /$ ncomms 16104

Shi, N., Liu, Q., Zhang, Q., Wang, T., and Ma, L. (2013). "High yield production of 5hydroxymethylfurfural from cellulose by high concentration of sulfates in biphasic system," Green Chem. 15(7), 1967-1974. DOI: 10.1039/c3gc40667a

Shi, S., Yang, P., Feng, W., Zhou, L., Lu, Q., Chen, W., and Che, W. (2018). "Wideband planar phased array antenna based on artificial magnetic conductor surface," Catal. Today 67(10), 1909-1913. DOI: 10.1109/TCSII.2019.2958984

Shu, R., Long, J., Xu, Y., Ma, L., Zhang, Q., Wang, T., Wang, C., Yuan, Z., and Wu, Q. (2016). "Investigation on the structural effect of lignin during the hydrogenolysis process," Bioresource Technol. 200, 14-22. DOI: 10.1016/j.biortech.2015.09.112

Thijs, V., Wouter, S., Tom, R., and Sels, B. F. (2018). "Perspective on lignin oxidation: Advances, challenges, and future directions," Topics Curr Chem. 376(4), 30. DOI: 10.1007/s41061-018-0207-2

Van den Bosch, S., Schutyser, W., Vanholme, R., Driessen, T., Koelewijn, S., Renders, T., de Meester, B., Huijgen, W. J. J., Dehaem, W., Lagrain, B., et al. (2015). "Reductive lignocellulose fractionation into soluble lignin-derived phenolic monomers and dimers and processable carbohydrate pulps," Energy. Environ. Sci. 8(6), 1748-1763. DOI: 10.1039/c5ee00204d

Wang, C., Wang, D., Wu, Z., Wang, Z., and Pan, Z. (2014). "Effect of W addition on the hydrodeoxygenation of 4-methylphenol over unsupported nimo sulfide catalysts," Appl. Catal. A-Gen. 476, 61-67. DOI: 10.1016/j.apcata.2014.02.010.

Wang, X., Li, X., Zhao, Q., Sun, W., Tade, M., and Liu, S. (2016). "Improved activity of $\mathrm{W}$-modified $\mathrm{MnOx}-\mathrm{TiO}_{2}$ catalysts for the selective catalytic reduction of $\mathrm{NO}$ with $\mathrm{NH}_{3}$," Chem. Eng. J. 288, 216-222. DOI: 10.1016/j.cej.2015.12.002

Wang, J., Li, W., Wang, H., Ogunbiyi, A. T., Dou, X., and Ma, Q. (2020). "Effects of the novel catalyst $\mathrm{Ni}-\mathrm{S}_{2} \mathrm{O}_{2}-\mathrm{K}_{2} \mathrm{O} / \mathrm{TiO}_{2}$ on efficient lignin depolymerization," $R S C A d v$. 10(14), 8558-8567. DOI: 10.1039/c9ra10675h

Wang, S., Zhao, Y., Lin, H., Chen, J., Zhu, L., and Luo, Z. (2017). “Conversion of C5 carbohydrates into furfural catalyzed by a Lewis acidic ionic liquid in renewable gamma-valerolactone," Green Chem. 19(16), 3869-3879. DOI: 10.1039/c7gc01298e

Wu, L., Hu, X., Wang, S., Hasan, M. D. M., Jiang, S., Li, T., and Li, C. Z. (2018). “Acidtreatment of bio-oil in methanol: The distinct catalytic behaviours of a mineral acid catalyst and a solid acid catalyst," Fuel 212, 412-421. DOI:

10.1016/j.fuel.2017.10.049

Wu, M., Lin, J., Xu. Z., Hua T., Lv, Y., Liu, Y., Pei, R., Wu, Q., and Liu, M. (2020). "Selective catalytic degradation of a lignin model compound into phenol over transition metal sulfates," RSC Adv. 10(5), 3013-3019. DOI: 10.1039/c9ra09706f 
Yan, F., Ma, R., Ma, X., Cui, K., Wu, K., Chen, M., and Li, Y. (2017). "Ethanolysis of kraft lignin to platform chemicals on a MoC1-x/Cu-MgAlOz, catalyst," Appl. Catal. B-Environ. 202, 305-313. DOI: 10.1016/j.apcatb.2016.09.030

Yang, J., Zhao, L., Liu, S., Wang, Y., and Dai, L. (2016). "High-quality bio-oil from onepot catalytic hydrocracking of kraft lignin over supported noble metal catalysts in isopropanol system," Bioresource Technol. 212, 302-310. DOI: 10.1016/j.biortech.2016.04.029

Yao, S., Mobley, J., Ralph, J., Crocker, M., and Meier, M. S. (2018). "Mechanochemical treatment facilitates two-step oxidative depolymerization of kraft lignin," ACS Sustain. Chem. Eng., 6(5), 5990-5998. DOI: 10.1021/acssuschemeng.7b04597

Zakzeski, J., Bruijnincx, P. C. A., Jongerius, A. L., and Weckhuysen, B. M. (2010). "The catalytic valorization of lignin for the production of renewable chemicals," Chem. Rev. 110(6), 3552-3599. DOI: 10.1021/cr900354u

Zhang, B., Li, W., Dou, X., Wang, J., Jin, L., Ogunbiyi, A. T., and Li, X. (2020). "Catalytic depolymerization of kraft lignin to produce liquid fuels via Ni-Sn metal oxide catalysts," Sustain. Energy. Fuels 4(3), 1332-1339. DOI: 10.1039/c9se01089k

Zhang, X., Tang, W., Zhang, Q., Wang, T., and Ma, L. (2018). "Hydrodeoxygenation of lignin-derived phenoic compounds to hydrocarbon fuel over supported Ni-based catalysts," Appl. Energy 227, 73-79. DOI: 10.1016/j.apenergy.2017.08.078

Zhang, X., Zhang, Q., Long, J., Xu, Y., Wang, T., Ma, L., and Li, Y. (2014). "Phenolics production through catalytic depolymerization of alkali lignin with metal chlorides," BioResources 9(2), 3347-3360. DOI: 10.15376/biores.9.2.3347-3360

Zhou, G., Jensen, P. A., Le, D. M., Knudsen, N. O., and Jensen, A. D. (2016). "Direct upgrading of fast pyrolysis lignin vapor over the HZSM-5 catalyst," Green Chem. 18(7), 1965-1975. DOI: 10.1039/c5gc01976a

Zhou, M., Xu, J., Jiang, J., and Sharma, B. K. (2019). “A review of microwave assisted liquefaction of lignin in hydrogen donor solvents: Effect of solvents and catalysts," Energies 11(11), article no. 2877. DOI: 10.3390/en11112877

Zhu, Q., Duan, H., Lin, B., Zhu, Y., Hu, Y., and Zhou, Y. (2019). "Higher acetone conversion obtained over a $\mathrm{TiO}_{2}-\mathrm{Pd}$ bifunctional catalyst for liquid-phase synthesis of methyl isobutyl ketone: The role of $\mathrm{Al}_{2} \mathrm{O}_{3}$ support," Catal. Lett. 149(9), 2636-2644. DOI: $10.1007 / \mathrm{s} 10562-019-02861-0$

Article submitted: April 23, 2021; Peer review completed: August 21, 2021; Revised version received and accepted: December 12, 2021; Published: December 17, 2021. DOI: 10.15376/biores.17.1.1062-1089 


\section{APPENDIX}

\section{Supplementary Information}

The basic chemical characteristics of Indulin $\mathrm{AT}^{\mathrm{TM}}$ are shown in Tables S1, S2, and S3.

Table S1. Component Compositions of Indulin ATTM (wt\%)

\begin{tabular}{|c|c|}
\hline & Indulin AT \\
\hline Klason lignin & 88.8 \\
\hline Acid-soluble lignin & 4.1 \\
\hline Total lignin & 92.9 \\
\hline Arabinan & 0.2 \\
\hline Galactan & 0.56 \\
\hline Glucan & 0.21 \\
\hline Xylan & 0.56 \\
\hline Total Sugars & 1.53 \\
\hline Ash & 2.01 \\
\hline
\end{tabular}

Table S2. Elemental and Methoxyl Contents

\begin{tabular}{|c|c|}
\hline & Indulin AT \\
\hline $\mathrm{C}(\%)$ & 65.5 \\
\hline $\mathrm{H}(\%)$ & 5.6 \\
\hline $\mathrm{O}(\%)$ & 25.2 \\
\hline $\mathrm{N}(\%)$ & 0.4 \\
\hline $\mathrm{S}(\%)$ & 3.3 \\
\hline $\mathrm{MeO}(\%)$ & 13.6 \\
\hline
\end{tabular}

Table S3. Substructures Estimated by 2D-HSQC NMR and ${ }^{13} \mathrm{C}$ NMR

\begin{tabular}{|c|c|c|}
\hline Substructures per 100 Ar & Indulin AT & Pine Milled Wood Lignin \\
\hline A: $\beta-O-4^{\prime}$ & 8.2 & 41 \\
\hline B: $\beta-5^{\prime}$ & 1.1 & 9 \\
\hline C: Dibenzodioxocin & 0.6 & 2 \\
\hline E: $\beta$ - $\beta^{\prime}$ pinoresinol & 1.2 & 2 \\
\hline F: $\beta-\beta^{\prime}$ secoisolariciresinol & 3.1 & - \\
\hline K: Enol ether & 1.5 & - \\
\hline H: Stilbene & 6.7 & 4 \\
\hline I: Coniferyl alcohol & 0.3 & - \\
\hline J: G-CH(OH)-COOH & 0.4 & \\
\hline Primary aliphatic $\mathrm{OH}$ & 31 & 114 \\
\hline Secondary aliphatic $\mathrm{OH}$ & 18 & 28 \\
\hline Total aliphatic OH & 49 & 95 \\
\hline Phenolic OH & 63 & 40 \\
\hline OCH3 & 68 & 68 \\
\hline Degree of condensation & 68 & \\
\hline
\end{tabular}

The monomer yield was calculated as follows internal standard method):

Weight of one monomer $=\lambda \times W_{A} / P A_{A} \times P A_{M}$

$W_{\mathrm{A}}$ : weight of acetophenone $(\mathrm{g})$

$P A_{A}$ : the peak area of acetophenone $(u V)$

PAм: the peak area of the monomer (uV)

$\lambda$ : the correcting coefficient, calculated by the sample of the monomer through the above formula 
There were some unquantifiable peaks in the GC chromatograph. The correcting coefficients of these unquantifiable peaks cannot be determined. Therefore, these unquantifiable peaks were estimated using the average of all correcting coefficients of known monomeric products. All the correcting coefficients are shown in Table S4. The yield of total monomers was calculated following Eqs. 1 and 2:

Yield $(\%)=$ Weight $(\mathrm{g}) /$ Weight of lignin $(0.5 \mathrm{~g}) \times 100$

Yield of total monomers $=$ Yield of all identified monomers + Yield of all unquantifiable monomers

Table S4. The Coefficients of Monomers

\begin{tabular}{|c|c|}
\hline Monomer & Coefficient \\
\hline Phenol & 0.97 \\
\hline 2-Methoxyphenol & 0.91 \\
\hline Veratrole & 0.87 \\
\hline 4-Ethylphenol & 0.84 \\
\hline 4-Methylguaiacol & 0.87 \\
\hline 3,4-Dimethoxytoluene & 0.90 \\
\hline 4-Ethylguaiacol & 0.90 \\
\hline Syringol & 0.76 \\
\hline Eugenol & 0.96 \\
\hline 4-Propylguaiacol & 0.98 \\
\hline Vanillina & 0.69 \\
\hline Isoeugenol & 0.69 \\
\hline Acetovanillone & 0.52 \\
\hline 2,6-Di-tert-butyl-4-methylphenol & 1.28 \\
\hline 4-Hydroxyl-3-Methoxypropiophenone & 0.77 \\
\hline Homovanillic acid & 0.21 \\
\hline Unquantifiable monomer & 0.83 \\
\hline
\end{tabular}


Table S5. Product Distribution of Monomers with Different Catalyst

\begin{tabular}{|c|c|c|c|c|c|c|c|}
\hline & \multicolumn{2}{|c|}{$270^{\circ} \mathrm{C}, 1 \mathrm{~h}$} & \multicolumn{3}{|c|}{$300^{\circ} \mathrm{C}, 1 \mathrm{~h}$} & \multicolumn{2}{|c|}{$300^{\circ} \mathrm{C}, 12 \mathrm{~h}$} \\
\hline Product Category & $\begin{array}{l}\text { W/Sn- } \\
\text { AIOx (\%) }\end{array}$ & $\begin{array}{c}\text { Ru- } \\
\text { W/Sn- } \\
\text { AlOx } \\
(\%)\end{array}$ & $\begin{array}{l}\text { Sn- } \\
\text { AlOx } \\
(\%)\end{array}$ & $\begin{array}{l}\text { W/Sn- } \\
\text { AlOx } \\
(\%)\end{array}$ & $\begin{array}{c}\text { Ru- } \\
\text { W/Sn- } \\
\text { AlOx } \\
(\%)\end{array}$ & $\begin{array}{l}\text { W/Sn- } \\
\text { AlOx } \\
(\%)\end{array}$ & $\begin{array}{c}\text { Ru- } \\
\text { W/Sn- } \\
\text { AlOx } \\
(\%)\end{array}$ \\
\hline Phenol & 0.00 & 0.00 & 0.01 & 0.01 & 0.06 & 0.07 & 0.06 \\
\hline 2-Methoxyphenol & 0.19 & 0.20 & 0.23 & 0.31 & 1.08 & 0.87 & 1.08 \\
\hline Veratrole & 0.00 & 0.00 & 0.02 & 0.02 & 0.09 & 0.11 & 0.09 \\
\hline 4-Ethylphenol & 0.01 & 0.01 & 0.01 & 0.01 & 0.12 & 0.04 & 0.12 \\
\hline 4-Methylguaiacol & 0.55 & 0.74 & 0.65 & 0.88 & 1.77 & 1.04 & 1.77 \\
\hline $\begin{array}{c}3,4- \\
\text { Dimethoxytoluene }\end{array}$ & 0.00 & 0.00 & 0.01 & 0.01 & 0.14 & 0.06 & 0.14 \\
\hline 4-Ethylguaiacol & 0.05 & 0.11 & 0.27 & 0.37 & 1.01 & 0.70 & 1.01 \\
\hline Syringol & 0.00 & 0.00 & 0.02 & 0.03 & 0.15 & 0.09 & 0.15 \\
\hline Eugenol & 0.05 & 0.13 & 0.13 & 0.14 & 0.25 & 0.24 & 0.25 \\
\hline 4-Propylguaiacol & 0.01 & 0.03 & 0.22 & 0.31 & 0.81 & 0.37 & 0.81 \\
\hline Vanillina & 0.38 & 0.23 & 0.39 & 0.55 & 0.07 & 0.54 & 0.07 \\
\hline Isoeugenol & 0.48 & 0.78 & 0.47 & 0.62 & 0.79 & 0.67 & 0.79 \\
\hline Acetovanillone & 0.18 & 0.14 & 0.27 & 0.33 & 0.20 & 0.22 & 0.20 \\
\hline $\begin{array}{l}\text { 2,6-Di-tert-butyl-4- } \\
\text { methylphenol }\end{array}$ & 0.06 & 0.05 & 0.11 & 0.15 & 0.15 & 0.31 & 0.15 \\
\hline $\begin{array}{c}\text { 4-Hydroxyl-3- } \\
\text { Methoxypropiophen } \\
\text { one }\end{array}$ & 0.05 & 0.06 & 0.13 & 0.18 & 0.12 & 0.37 & 0.12 \\
\hline Homovanillic acid & 0.93 & 0.92 & 1.41 & 1.82 & 1.29 & 1.81 & 1.29 \\
\hline $\begin{array}{l}\text { Total identified } \\
\text { monomers }\end{array}$ & 2.95 & 3.40 & 4.34 & 5.74 & 8.08 & 7.51 & 8.08 \\
\hline $\begin{array}{c}\text { Total unquantifiable } \\
\text { monomers }\end{array}$ & 1.67 & 1.51 & 1.63 & 2.07 & 7.60 & 7.27 & 7.60 \\
\hline Total monomers & 4.62 & 4.91 & 5.97 & 7.81 & 15.69 & 14.78 & 15.69 \\
\hline
\end{tabular}

Conditions: $0.5 \mathrm{~g}$ lignin, $0.1 \mathrm{~g}$ catalyst, $2 \mathrm{MPa} \mathrm{H}_{2}$, and $900 \mathrm{rpm}$ 
Table S6. Product Distribution at Different Temperature and Reaction Times

\begin{tabular}{|c|c|c|c|c|c|c|}
\hline $\begin{array}{c}\text { Reaction } \\
\text { Time }(\mathrm{h})\end{array}$ & $\begin{array}{c}\text { Reaction } \\
\text { Temperature } \\
\left({ }^{\circ} \mathrm{C}\right)\end{array}$ & $\begin{array}{c}\text { Solid } \\
\text { Product } \\
(\%)\end{array}$ & $\begin{array}{c}\text { Gas } \\
\text { Product } \\
(\%)\end{array}$ & $\begin{array}{c}\text { Liquid } \\
\text { Product } \\
(\%)\end{array}$ & $\begin{array}{c}\text { Petroleum } \\
\text { Ether Soluble } \\
\text { Product }(\%)\end{array}$ & $\begin{array}{c}\text { Total } \\
\text { Monomers } \\
(\%)\end{array}$ \\
\hline 1 & 270 & 7.36 & 1.14 & 91.50 & 9.24 & 4.91 \\
\hline 3 & 270 & 10.88 & 1.67 & 87.45 & 13.08 & 6.71 \\
\hline 6 & 270 & 5.01 & 1.92 & 93.07 & 15.01 & 6.99 \\
\hline 12 & 270 & 3.03 & 2.16 & 94.81 & 20.47 & 7.49 \\
\hline 1 & 290 & 22.28 & 2.01 & 75.71 & 17.25 & 6.50 \\
\hline 3 & 290 & 36.16 & 2.54 & 61.30 & 22.63 & 7.90 \\
\hline 6 & 290 & 26.60 & 2.83 & 70.57 & 28.37 & 11.19 \\
\hline 12 & 290 & 28.93 & 3.25 & 67.82 & 25.46 & 10.39 \\
\hline 1 & 300 & 33.14 & 2.95 & 63.91 & 20.19 & 7.48 \\
\hline 3 & 300 & 14.11 & 3.32 & 82.57 & 30.16 & 10.94 \\
\hline 6 & 300 & 7.10 & 3.54 & 89.36 & 35.53 & 11.42 \\
\hline 12 & 300 & 1.92 & 3.76 & 94.32 & 59.86 & 15.69 \\
\hline 1 & 310 & 27.41 & 3.54 & 69.05 & 34.60 & 10.03 \\
\hline 3 & 310 & 24.44 & 3.96 & 71.60 & 42.00 & 12.53 \\
\hline 6 & 310 & 0.32 & 4.13 & 95.55 & 50.54 & 14.38 \\
\hline 12 & 310 & 0.38 & 4.34 & 95.28 & 53.58 & 17.22 \\
\hline
\end{tabular}

Conditions: $0.5 \mathrm{~g}$ lignin, $0.1 \mathrm{~g} \mathrm{Ru}-\mathrm{W} / \mathrm{Sn}_{-} \mathrm{AlO}_{\mathrm{x}}, 2 \mathrm{MPa} \mathrm{H}_{2}$, and $900 \mathrm{rpm}$

Table S7. Pt. 1: Product Distribution at Different Temperature and Reaction Times

\begin{tabular}{|c|c|c|c|c|c|c|c|c|}
\hline & \multicolumn{4}{|c|}{$270^{\circ} \mathrm{C}$} & \multicolumn{4}{|c|}{$290^{\circ} \mathrm{C}$} \\
\hline & $\begin{array}{l}1 \mathrm{~h} \\
(\%)\end{array}$ & $\begin{array}{l}3 \mathrm{~h} \\
(\%)\end{array}$ & $\begin{array}{l}6 \mathrm{~h} \\
(\%)\end{array}$ & $\begin{array}{l}12 \mathrm{~h} \\
(\%)\end{array}$ & $\begin{array}{l}1 \mathrm{~h} \\
(\%)\end{array}$ & $\begin{array}{l}3 \mathrm{~h} \\
(\%)\end{array}$ & $6 \mathrm{~h}(\%)$ & $\begin{array}{l}12 \mathrm{~h} \\
(\%)\end{array}$ \\
\hline Phenol & 0.00 & 0.00 & 0.00 & 0.01 & 0.00 & 0.00 & 0.03 & 0.03 \\
\hline 2-Methoxyphenol & 0.20 & 0.44 & 0.43 & 0.38 & 0.36 & 0.47 & 1.07 & 0.92 \\
\hline Veratrole & 0.00 & 0.00 & 0.01 & 0.00 & 0.00 & 0.01 & 0.01 & 0.01 \\
\hline 4-Ethylphenol & 0.01 & 0.02 & 0.03 & 0.03 & 0.03 & 0.03 & 0.06 & 0.07 \\
\hline 4-Methylguaiacol & 0.74 & 0.83 & 0.89 & 1.11 & 0.90 & 1.37 & 2.08 & 2.29 \\
\hline 3,4-Dimethoxytoluene & 0.00 & 0.00 & 0.01 & 0.00 & 0.00 & 0.01 & 0.03 & 0.04 \\
\hline 4-Ethylguaiacol & 0.11 & 0.33 & 0.43 & 0.54 & 0.33 & 0.62 & 1.03 & 0.91 \\
\hline Syringol & 0.00 & 0.01 & 0.03 & 0.03 & 0.01 & 0.03 & 0.07 & 0.10 \\
\hline Eugenol & 0.13 & 0.19 & 0.21 & 0.08 & 0.12 & 0.13 & 0.15 & 0.13 \\
\hline 4-Propylguaiacol & 0.03 & 0.10 & 0.17 & 0.36 & 0.08 & 0.27 & 0.68 & 0.80 \\
\hline Vanillina & 0.23 & 0.20 & 0.22 & 0.15 & 0.21 & 0.16 & 0.17 & 0.07 \\
\hline Isoeugenol & 0.78 & 1.12 & 1.04 & 0.69 & 0.82 & 0.69 & 0.71 & 0.13 \\
\hline Acetovanillone & 0.14 & 0.20 & 0.21 & 0.21 & 0.22 & 0.23 & 0.30 & 0.19 \\
\hline $\begin{array}{c}\text { 2,6-Di-tert-butyl-4- } \\
\text { methylphenol }\end{array}$ & 0.05 & 0.11 & 0.13 & 0.17 & 0.10 & 0.14 & 0.19 & 0.14 \\
\hline $\begin{array}{c}\text { 4-Hydroxyl-3- } \\
\text { Methoxypropiophenone }\end{array}$ & 0.06 & 0.10 & 0.09 & 0.14 & 0.09 & 0.13 & 0.18 & 0.13 \\
\hline Homovanillic acid & 0.92 & 1.41 & 1.37 & 1.54 & 1.20 & 1.44 & 1.42 & 1.52 \\
\hline Total identified monomers & 3.40 & 5.06 & 5.26 & 5.46 & 4.47 & 5.73 & 8.20 & 7.48 \\
\hline $\begin{array}{c}\text { Total unquantifiable } \\
\text { monomers }\end{array}$ & 1.51 & 1.64 & 1.73 & 2.03 & 2.03 & 2.17 & 2.41 & 2.91 \\
\hline Total monomers & 4.91 & 6.71 & 6.99 & 7.49 & 6.50 & 7.90 & 11.19 & 10.39 \\
\hline
\end{tabular}

Conditions: $0.5 \mathrm{~g}$ lignin, $0.1 \mathrm{~g} \mathrm{Ru}-\mathrm{W} / \mathrm{Sn}-\mathrm{AlOx}, 2 \mathrm{MPa} \mathrm{H} 2$, and $900 \mathrm{rpm}$ 
Table S7. Part 2: Product Distribution at Different Temperature and with Various Reaction Times

\begin{tabular}{|c|c|c|c|c|c|c|c|c|}
\hline & \multicolumn{4}{|c|}{$300^{\circ} \mathrm{C}$} & \multicolumn{4}{c|}{$310^{\circ} \mathrm{C}$} \\
\hline & $\begin{array}{c}1 \mathrm{~h} \\
(\%)\end{array}$ & $3 \mathrm{~h}(\%)$ & $\begin{array}{c}6 \mathrm{~h} \\
(\%)\end{array}$ & $\begin{array}{c}12 \mathrm{~h} \\
(\%)\end{array}$ & $\begin{array}{c}1 \mathrm{~h} \\
(\%)\end{array}$ & $\begin{array}{c}3 \mathrm{~h} \\
(\%)\end{array}$ & $\begin{array}{c}6 \mathrm{~h} \\
(\%)\end{array}$ & $\begin{array}{c}12 \mathrm{~h} \\
(\%)\end{array}$ \\
\hline Phenol & 0.02 & 0.04 & 0.05 & 0.06 & 0.03 & 0.05 & 0.06 & 0.08 \\
\hline 2-Methoxyphenol & 0.59 & 0.97 & 1.08 & 1.08 & 0.88 & 1.09 & 1.08 & 0.88 \\
\hline Veratrole & 0.02 & 0.02 & 0.03 & 0.09 & 0.02 & 0.06 & 0.08 & 0.13 \\
\hline 4-Ethylphenol & 0.04 & 0.07 & 0.08 & 0.12 & 0.06 & 0.09 & 0.10 & 0.14 \\
\hline 4-Methylguaiacol & 1.67 & 1.87 & 1.93 & 1.77 & 1.50 & 2.02 & 1.97 & 1.70 \\
\hline 3,4-Dimethoxytoluene & 0.01 & 0.03 & 0.06 & 0.14 & 0.05 & 0.07 & 0.09 & 0.12 \\
\hline 4-Ethylguaiacol & 0.67 & 0.95 & 1.01 & 1.01 & 0.89 & 1.07 & 1.07 & 0.98 \\
\hline Syringol & 0.02 & 0.10 & 0.14 & 0.15 & 0.07 & 0.15 & 0.17 & 0.13 \\
\hline Eugenol & 0.16 & 0.24 & 0.22 & 0.25 & 0.24 & 0.27 & 0.28 & 0.30 \\
\hline 4-Propylguaiacol & 0.29 & 0.71 & 0.82 & 0.81 & 0.42 & 0.76 & 0.84 & 0.70 \\
\hline Vanillina & 0.17 & 0.12 & 0.07 & 0.07 & 0.18 & 0.09 & 0.09 & 0.08 \\
\hline Isoeugenol & 0.68 & 0.26 & 0.20 & 0.79 & 0.62 & 0.32 & 0.55 & 1.14 \\
\hline Acetovanillone & 0.21 & 0.22 & 0.16 & 0.20 & 0.27 & 0.21 & 0.22 & 0.22 \\
\hline $\begin{array}{c}\text { 2,6-Di-tert-butyl-4- } \\
\text { methylphenol }\end{array}$ & 0.14 & 0.15 & 0.15 & 0.15 & 0.17 & 0.16 & 0.17 & 0.21 \\
\hline $\begin{array}{c}\text { 4-Hydroxyl-3- } \\
\text { Methoxypropiophenone }\end{array}$ & 0.11 & 0.12 & 0.13 & 0.12 & 0.15 & 0.14 & 0.14 & 0.13 \\
\hline Homovanillic acid & 1.36 & 1.50 & 1.38 & 1.29 & 1.65 & 1.28 & 1.51 & 1.32 \\
\hline Total identified monomers & 6.15 & 7.37 & 7.53 & 8.08 & 7.22 & 7.84 & 8.43 & 8.27 \\
\hline $\begin{array}{c}\text { Total unquantifiable } \\
\text { monomers }\end{array}$ & 1.33 & 3.57 & 3.89 & 7.60 & 2.81 & 4.69 & 5.96 & 8.96 \\
\hline Total monomers & 7.48 & 10.94 & 11.42 & 15.69 & 10.03 & 12.53 & 14.38 & 17.22 \\
\hline Condilions: 0.5 lignin
\end{tabular}

Conditions: $0.5 \mathrm{~g}$ lignin, $0.1 \mathrm{~g} \mathrm{Ru}-\mathrm{W} / \mathrm{Sn}-\mathrm{AlO}_{\mathrm{x}}, 2 \mathrm{MPa} \mathrm{H}_{2}$, and $900 \mathrm{rpm}$ 

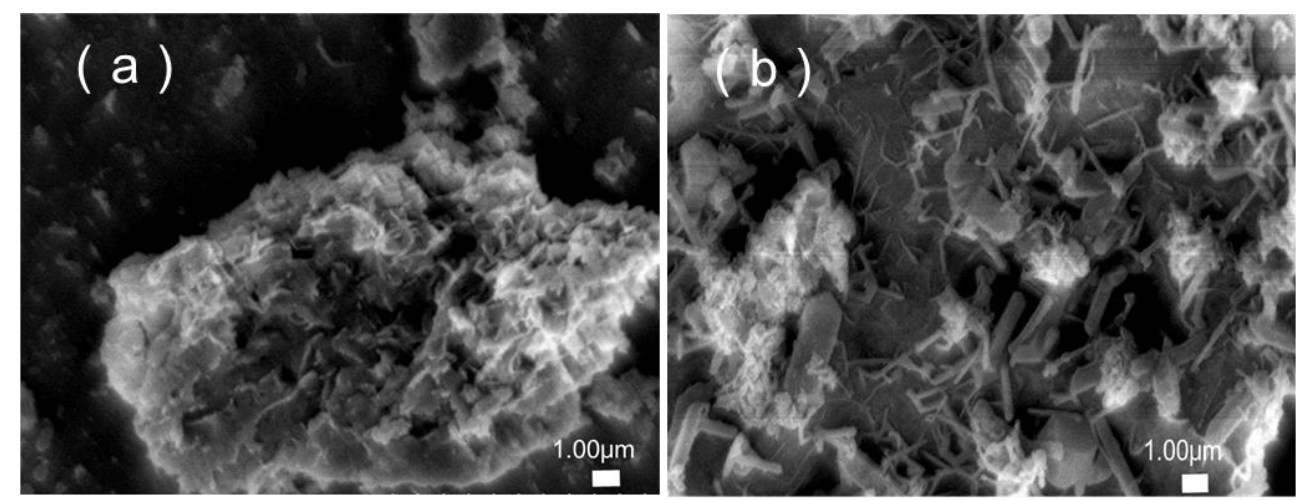

SU8200 2.0KV $2.7 \mathrm{~mm} \times 50.0 \mathrm{k}$ SE ( UL ) SU8200 2.0KV 2.7mm×50.0k SE ( UL )
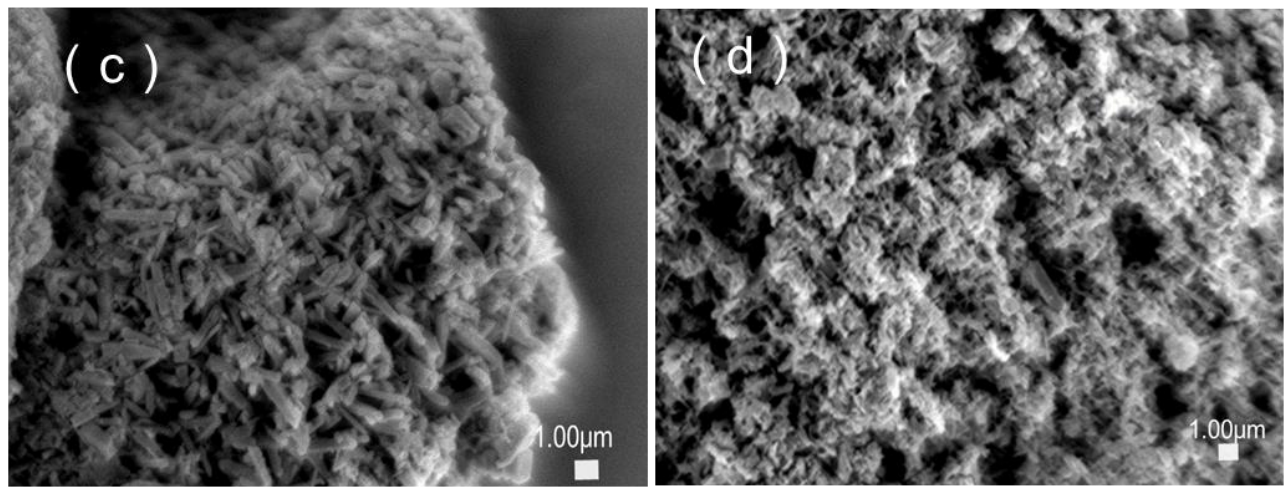

SU8200 2.0KV $2.6 \mathrm{~mm} \times 40.0 \mathrm{k}$ SE ( UL )

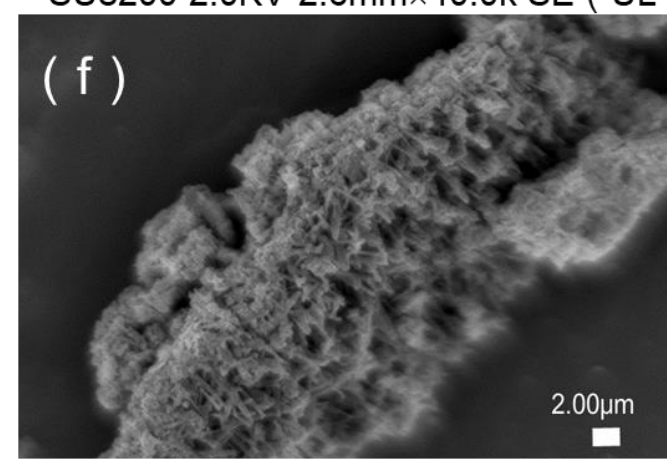

SU8200 2.0KV 2.6mm $\times 30.0 \mathrm{k}$ SE ( UL )

SU8200 2.0KV 2.6mm $\times 20.0 \mathrm{k}$ SE ( UL )

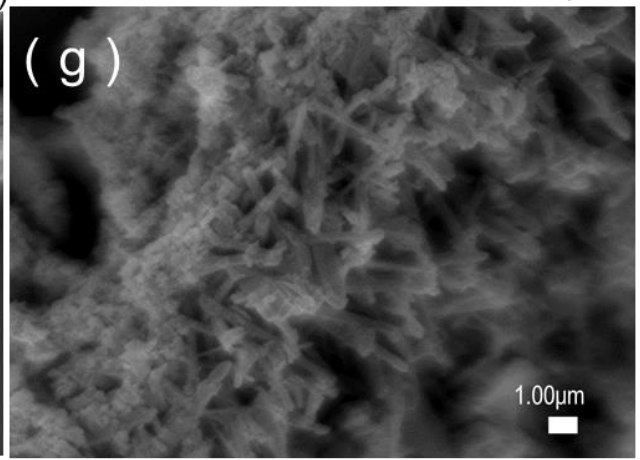

SU8200 2.0KV 2.6mm×50.0k SE ( UL )

Fig. S1. SEM images of $\mathrm{Sn}-\mathrm{AlO}_{x}(\mathrm{a}, \mathrm{b}), \mathrm{W} / \mathrm{Sn}-\mathrm{AlO}_{x}(\mathrm{c}, \mathrm{d})$ and $\mathrm{Ru}-\mathrm{W} / \mathrm{Sn}-\mathrm{AlOx}(\mathrm{f}, \mathrm{g})$ 


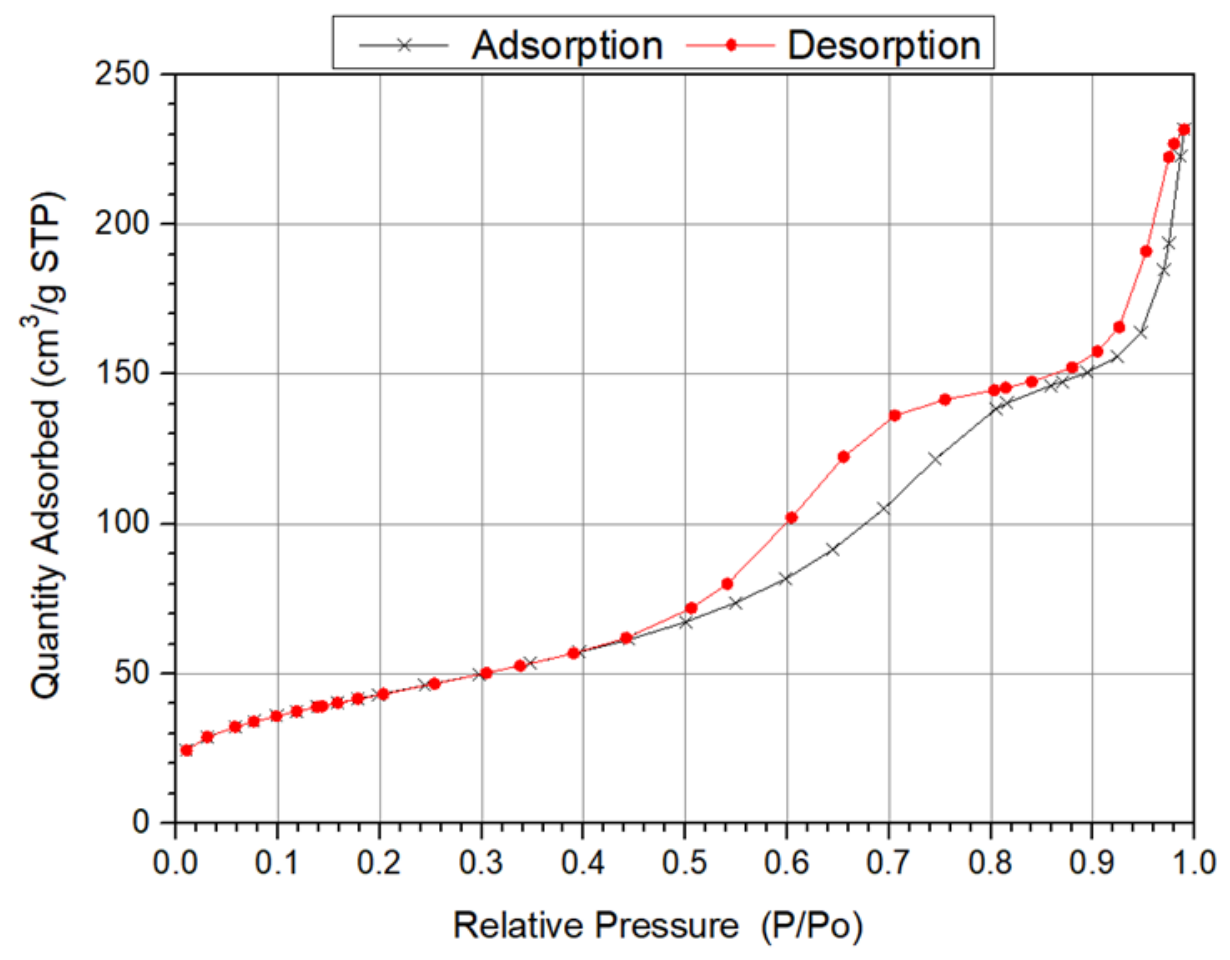

Fig. S2. The $\mathrm{N}_{2}$ adsorption-desorption isotherms images of $\mathrm{Sn}-\mathrm{AlOx}$

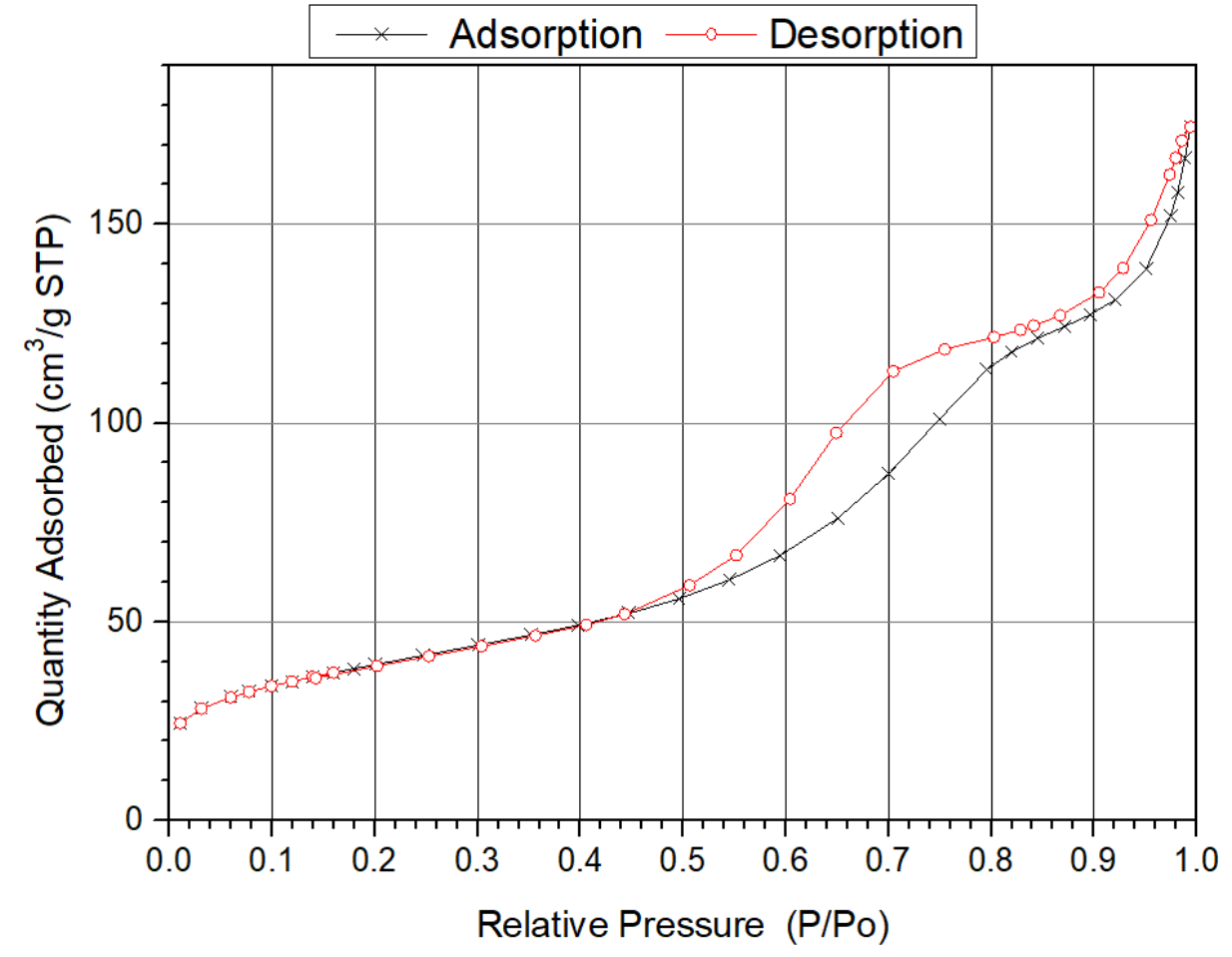

Fig. S3. The $\mathrm{N}_{2}$ adsorption-desorption isotherms images of $\mathrm{Ru}-\mathrm{W} / \mathrm{Sn}-\mathrm{AlO} \times$ 


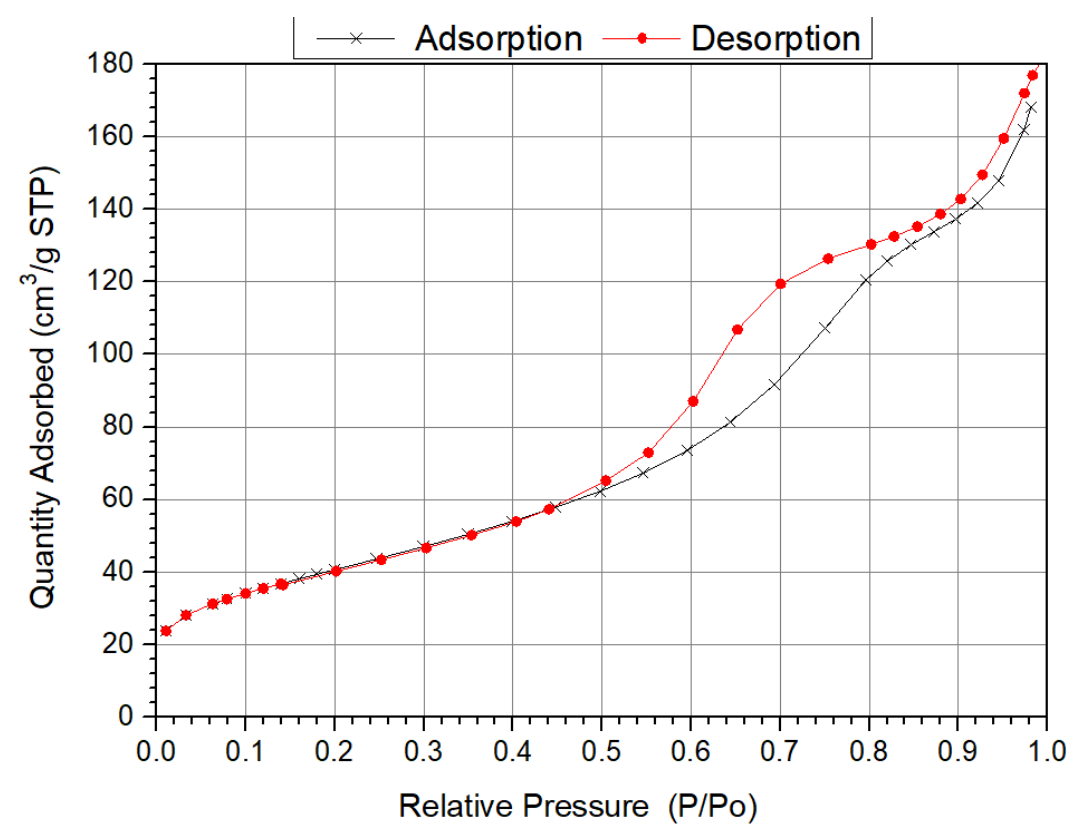

Fig. S4. The $\mathrm{N}_{2}$ adsorption-desorption isotherms images of $\mathrm{W} / \mathrm{Sn}-\mathrm{AlO} \mathrm{X}_{\mathrm{x}}$
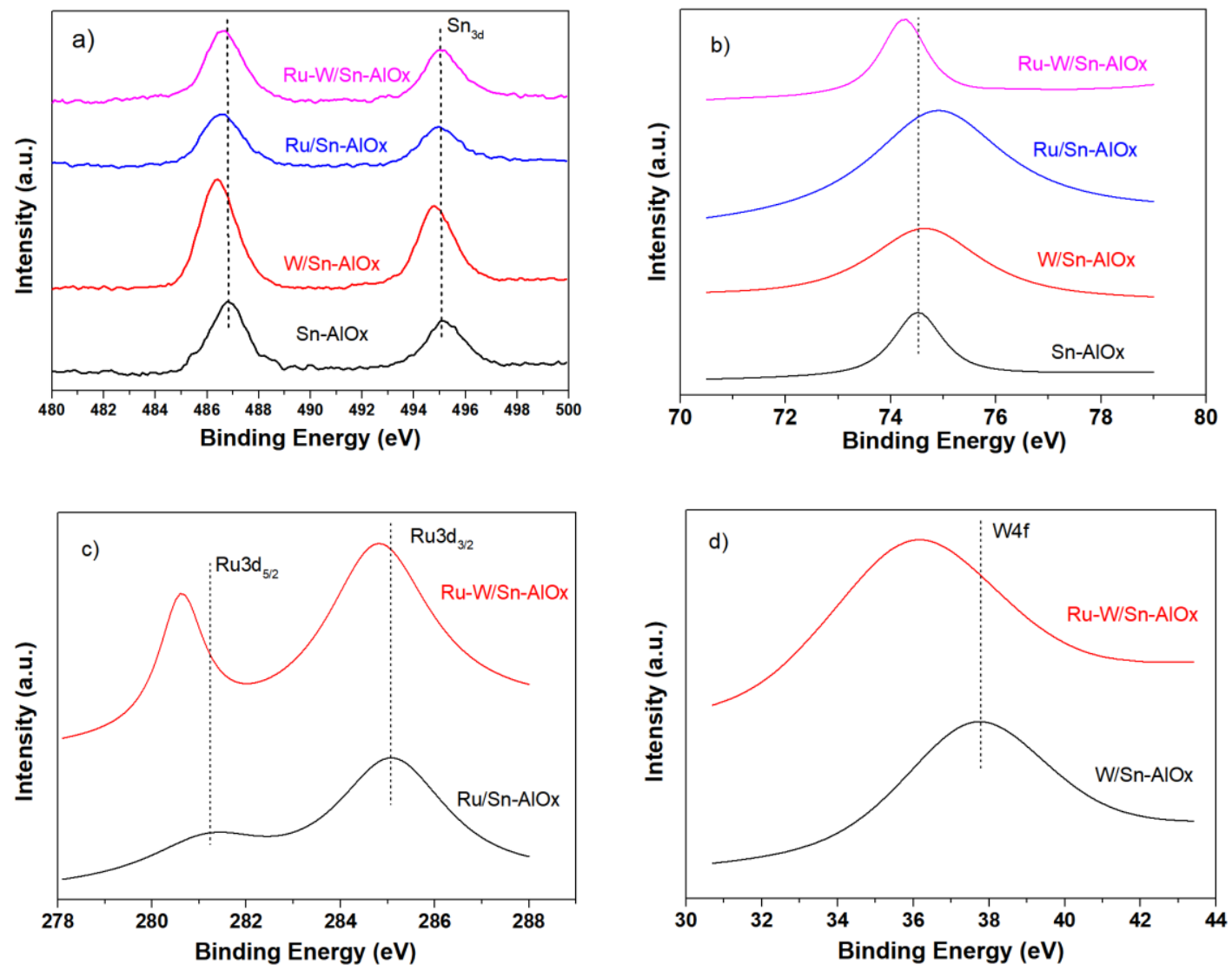

Fig. S5. The XPS spectra of Sn3d (a), Al2p (b), Ru3d (c), and W4f (d) from Sn-AlOx, W/Sn-AlOx, $\mathrm{Ru} / \mathrm{Sn}-\mathrm{AlOx}$ and Ru-W/Sn- AlOx 


\section{bioresources.com}
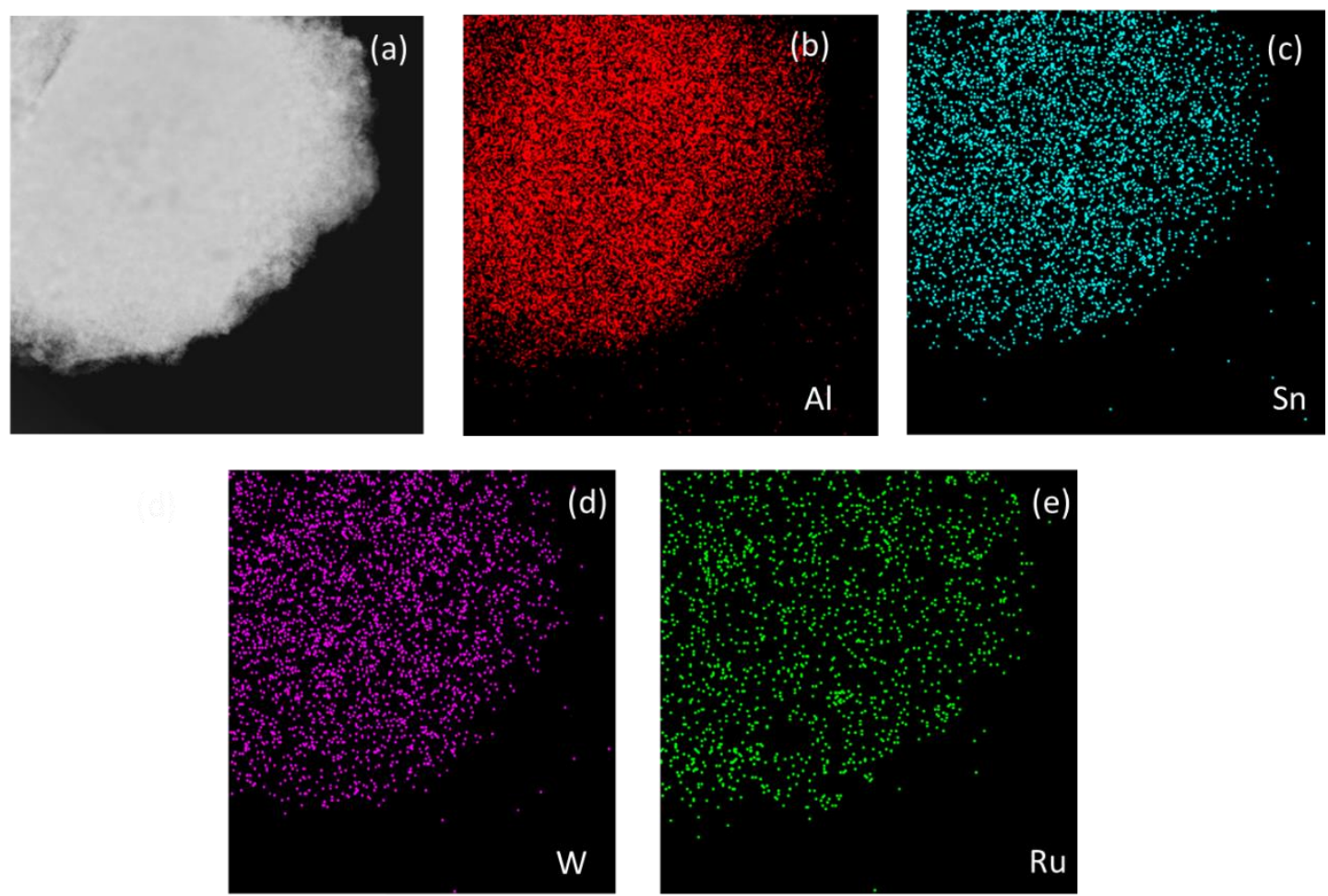

Fig. S6. HRTEM image of Ru-W/Sn- AlOx (a) and different metal dispersions for Al (b), Sn (c), W (d), and $\mathrm{Ru}(\mathrm{e})$ of the Ru-W/Sn- AlOx

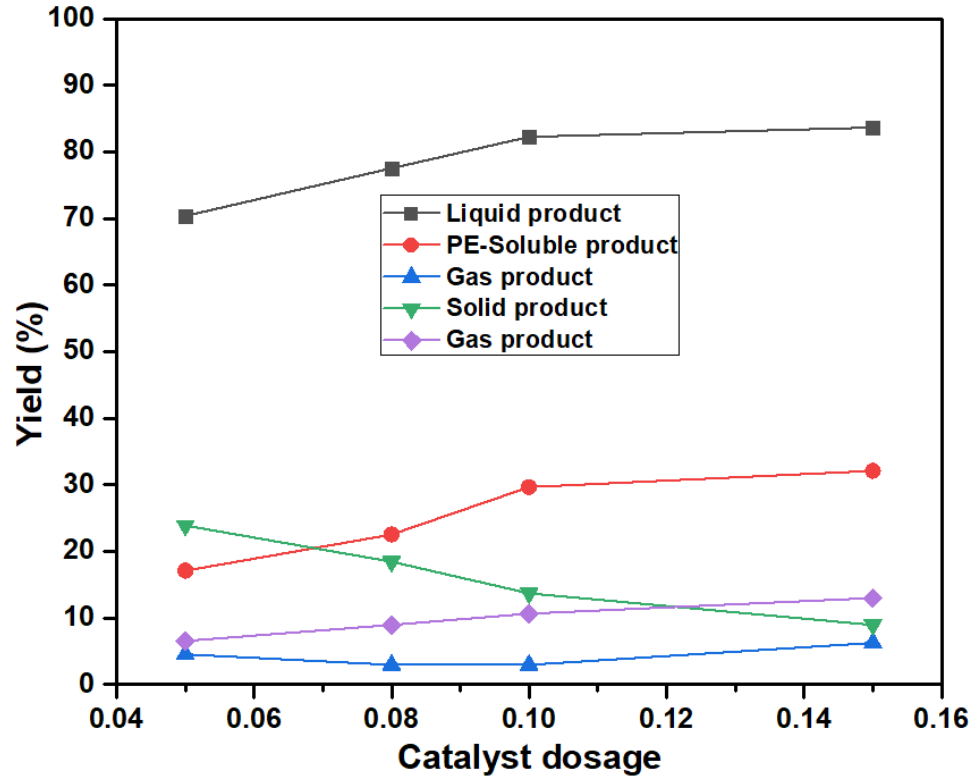

Fig. S7. Effect of the catalyst dosage on lignin depolymerization; conditions: $0.5 \mathrm{~g}$ lignin, $300^{\circ} \mathrm{C}$, $3 \mathrm{~h}, 2 \mathrm{MPa} \mathrm{H}_{2}$, and $900 \mathrm{rpm}$ 